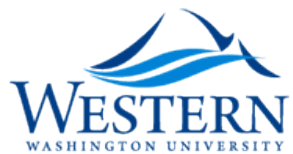

Western Washington University

Western CEDAR

$4-2012$

\title{
Late Holocene Rupture History of the Alpine Fault in South Westland, New Zealand
}

Kelvin Berryman

Alan Cooper

Richard Norris

Pilar Villamor

Rupert Sutherland

See next page for additional authors

Follow this and additional works at: https://cedar.wwu.edu/geology_facpubs

Part of the Geology Commons, and the Geophysics and Seismology Commons

\section{Recommended Citation}

Berryman, K., Cooper, A.F., Norris, R.J., Villamor, P., Sutherland, R., Wright, T., Schermer, E.R., Langridge, R., and Biasi, G., Late Holocene Rupture History of the Alpine Fault in South Westland, New Zealand, Bulletin Seismological Society of America 102:2, p 620-638, 2012 (C) Seismological Society of America 
Authors

Kelvin Berryman, Alan Cooper, Richard Norris, Pilar Villamor, Rupert Sutherland, Trevor Wright, Elizabeth R. Schermer, Robert Langridge, and Glenn Biasi 


\section{Bulletin of the Seismological Society of America}

This copy is for distribution only by

the authors of the article and their institutions in accordance with the Open Access Policy of the Seismological Society of America.

For more information see the publications section of the SSA website at www.seismosoc.org

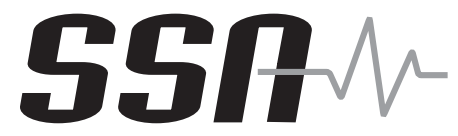

The Seismological Society of America 400 Evelyn Ave., Suite 201

Albany, CA 94706-1375

(510) 525-5474; FAX (510) 525-7204

www.seismosoc.org 


\title{
Late Holocene Rupture History of the Alpine Fault in South Westland, New Zealand
}

\author{
by Kelvin Berryman, Alan Cooper, Richard Norris, Pilar Villamor, Rupert Sutherland, \\ Trevor Wright, Elizabeth Schermer, Robert Langridge, and Glenn Biasi
}

\begin{abstract}
Strata and fault relationships revealed in five trenches excavated across the recent trace of the Alpine fault at the Haast, Okuru, and Turnbull Rivers, South Westland, New Zealand, record the three most recent surface-faulting events. Using back-stripping techniques to remove the three faulting events and the sedimentary units associated with the faulting restores the cross-sections to gravel-bed floodplains at the Haast and Okuru Rivers, at about A.D. 750. Horizontal and vertical offsets of stream channels and terrace risers reveal characteristic displacements of about 8-9 m dextral and up to $1 \mathrm{~m}$ vertical per event. Cumulative dextral displacement is $25 \pm 3 \mathrm{~m}$ in the past three events. The most recent surface-rupture event was probably in A.D. 1717, and the next prior events were about A.D. $1230 \pm 50$ and about A.D.750 \pm 50 . The timing of these events is consistent with past large-great earthquakes on the southern section of the Alpine fault inferred from off-fault data, but there are fewer events identified in trenches. Our three-event dataset indicates the average surface-rupture recurrence interval for the South Westland section of the fault is about 480 years, much longer than the current elapsed time of 295 years. Therefore, the Alpine fault in South Westland may not be close to rupture as is often speculated.
\end{abstract}

\section{Introduction}

The Alpine fault is the principal structure defining the Australian-Pacific plate boundary in the South Island of New Zealand (Wellman, 1979; Norris et al., 1990; Berryman et al., 1992; Sutherland et al., 2000, 2006; Barnes, 2009; Langridge et al., 2010). It is widely regarded as one of the major active faults of the world (Sylvester, 1988). This paper presents the first on-fault paleoseismic results from the southern $300 \mathrm{~km}$ of the fault on land.

The broad tectonic setting of the region has been defined by marine magnetic data and GPS velocities. The plates are calculated to be moving at a relative rate of about $38 \mathrm{~mm} / \mathrm{yr}$ in southern South Island (Fig. 1), resolved into $36 \mathrm{~mm} / \mathrm{yr}$ parallel to the fault and $10 \mathrm{~mm} / \mathrm{yr}$ perpendicular to it (DeMets et al., 1994; Sutherland, 1999; Beavan and Haines, 2001; Wallace et al., 2007). Studies of displaced Pliocene (Sutherland, 1994; Sutherland et al., 1995) and Quaternary deposits (e.g., Berryman et al., 1992; Cooper and Norris, 1995; Norris and Cooper, 1997; Norris and Cooper, 2001; Sutherland et al., 2006) for the southern, on-land section of the fault have provided a most-recent estimate of $23 \pm 2 \mathrm{~mm} / \mathrm{yr}$ strike-slip displacement, and smaller and variable vertical slip rate, over at least the past 3.5 Ma. Large ground ruptures of around $8 \mathrm{~m}$ dextral and $\leq 1 \mathrm{~m}$ vertical displacement have occurred in the past on the southern section of the fault (Hull and Berryman, 1986; Cooper and Norris, 1990; Sutherland and
Norris, 1995; Sutherland et al., 2007) during the past circa 1000 years.

The dip of the fault varies along its length, resulting in distinctive geomorphic sections to the fault (Berryman et al., 1992) (Fig. 1), but there are few data to constrain past rupture lengths or the location and stability of fault segments. Wright et al. (1997), Yetton et al. (1998), Wells et al. (1998), Berryman et al. (2001), Cullen et al. (2003), and Wells and Goff (2007) have established a chronology of fault rupture based largely on landscape change events at various locations along the fault. At least five events in the last 1000 years have been recognized from trenching, and stratigraphic, geomorphic, and landscape evidence of episodic, catastrophic, landsliding in the southern Alps, and alluviation of the coastal plain. The dates of these earthquakes have been determined as A.D. 1826, A.D. 1717 ( $\pm 2-3$ yrs), A.D. 1615 ( $\pm 5-10$ yrs), circa A.D. 1460, and circa A.D. 1230 Evidence for the circa A.D. 1615 and circa A.D. 1460 earthquakes along the southern section of the fault from Haast southward has been described as weak by Wells and Goff (2007).

This paper reports the results from five trenches excavated at three sites (up to $12 \mathrm{~km}$ apart) on the southern section of the fault in the vicinity of Haast (Fig. 1). The primary objective of the work has been to obtain on-fault information 


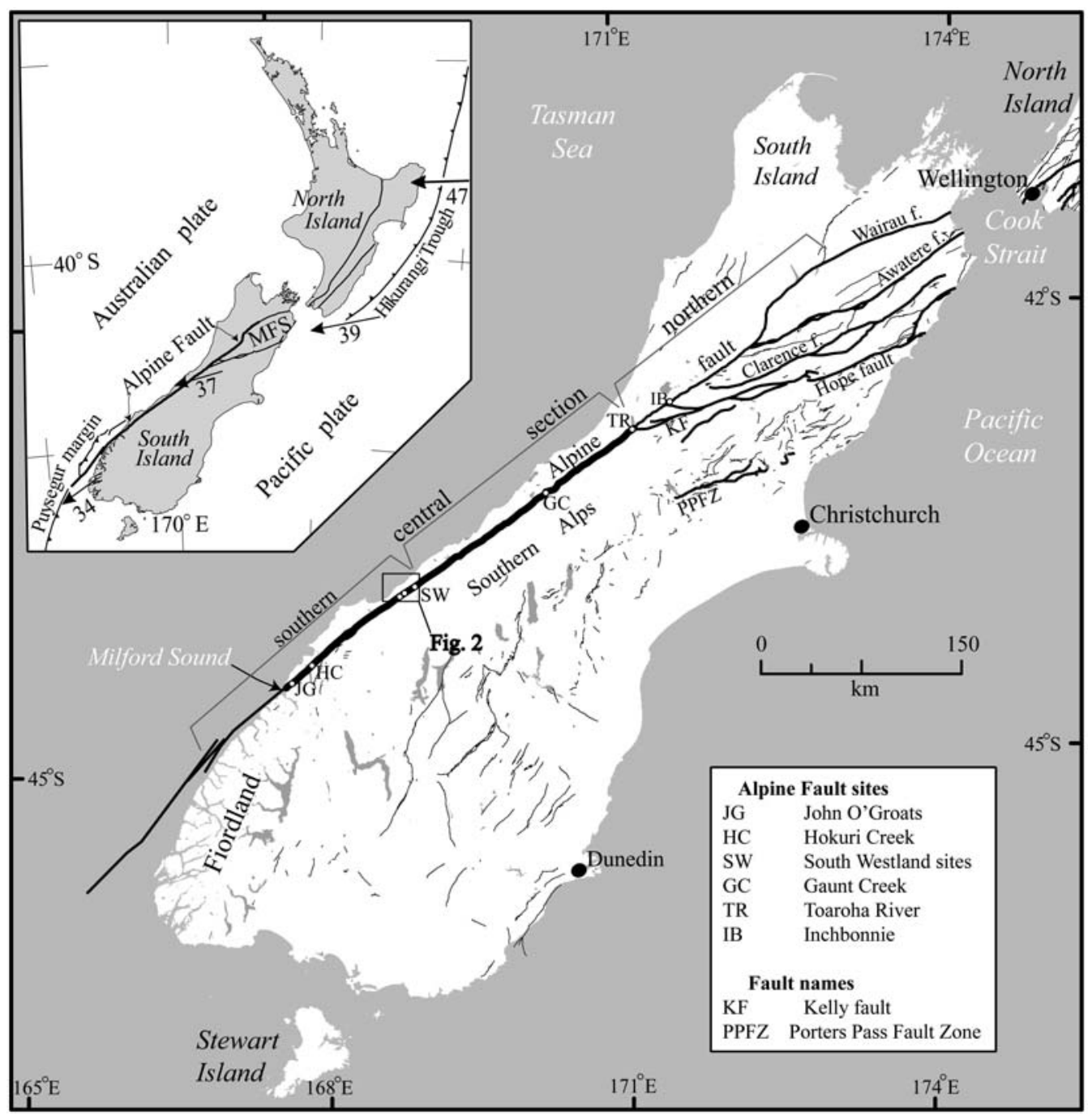

Figure 1. Sketch of the Alpine fault, South Island, New Zealand, showing the extent of geomorphic sections, localities mentioned in the text, and extension of the Alpine fault into the strike-slip fault belt in northeast South Island. Study area in South Westland indicated by Figure 2 box. Inset shows the tectonic setting with major plate boundary features, locations of subduction margins and Nuvel $1 \mathrm{~A}$ plate velocity vectors of the Pacific plate relative to the Australian plate.

on the timing and size of the past several surface-rupture events on this section of the Alpine fault.

\section{Alpine Fault in South Westland}

The trace of the Alpine fault in South Westland in general, and in the 12-km section of the fault between the Haast and Turnbull Rivers where our trenches were located (Figs. 1, 2), has been known for many years (e.g., Wellman, 1953; Cooper and Bishop, 1979). The sites have provided some estimates of single-event horizontal and vertical displacements (Cooper and Bishop, 1979; Berryman et al., 1992), but the absence of dating of the young terraces displaced by the fault has limited the paleoseismic potential of these sites. Cooper and Norris (1995) reported on the age and displacement of fluvial terraces on the north side of the Haast River and obtained a minimum dextral slip rate of $23.5 \mathrm{~mm} / \mathrm{yr}$ for the past $4 \mathrm{ka}$, but the site was not able to yield information on the timing of individual surface-rupture events.

This section of the fault, unlike the section of the fault north of the Haast River, presents some opportunity for paleoseismic investigation because the recent trace of the fault is located a few hundred meters outboard of the rangefront. This is partly the result of the major late Pleistocene glacier of the Haast valley trimming the weak rocks of the cataclasite and mylonite zones on the hanging wall of the fault, and partly because the near-surface dip of the fault is steep, and the range is not being overthrust to the same extent as along the central section where near-surface fault dip is $\approx 40^{\circ}-50^{\circ}$ (Figs. 1, 2). Thus, the fault trace in the Haast area is not prone to being covered by slope debris resulting from rangefront collapse that occurs with each fault rupture event and associated severe ground shaking at sites along the central section. 
(a)

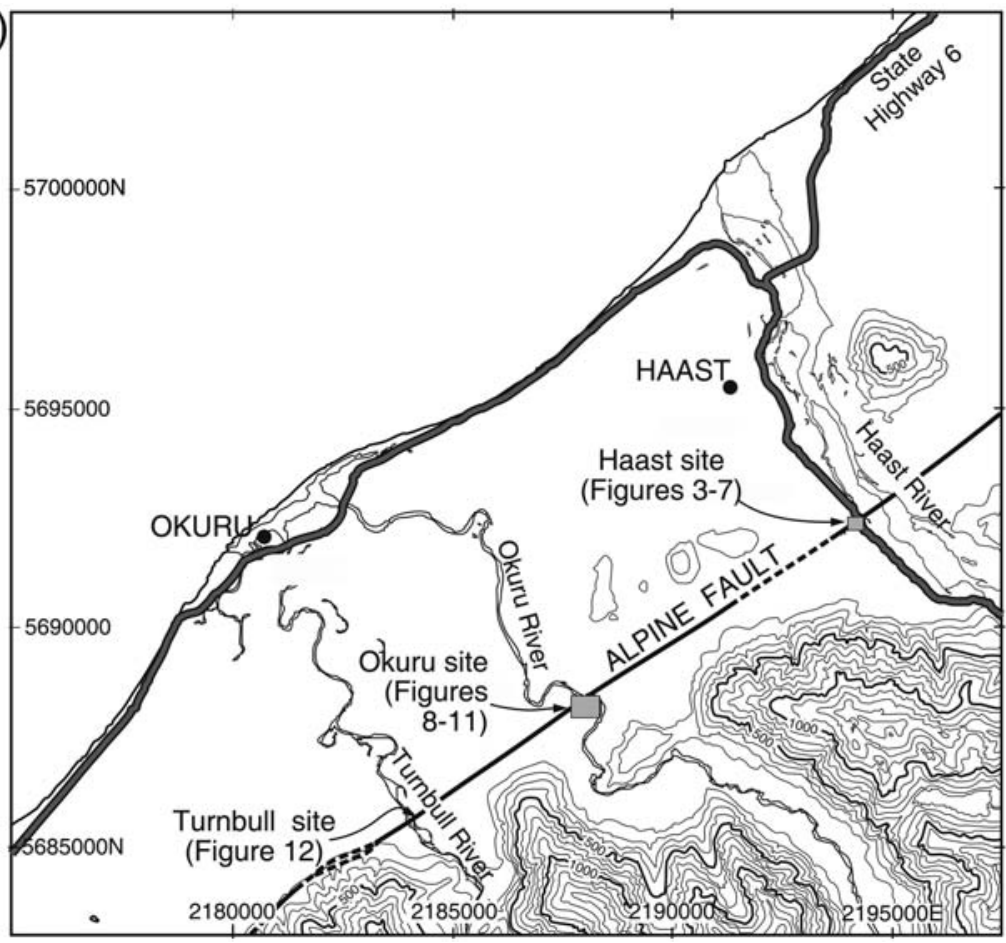

(b)

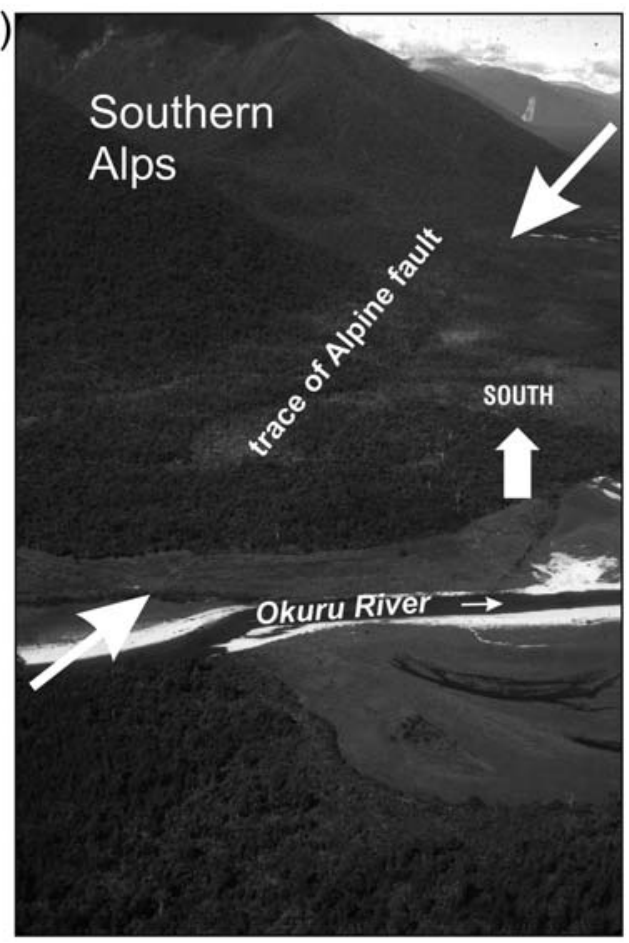

Figure 2. (a) Topographic map of the study area in South Westland showing traces of the Alpine fault between the Haast and Turnbull rivers and locations of further figures. (b) Aerial oblique photo looking south along the trace of the Alpine fault with Okuru River in the foreground, southern Alps to the east, and extensive forest cover except for a few locations.

\section{This Study}

This paper presents the results obtained from detailed topographic survey and five trench excavations carried out on the south side of the Haast River adjacent to the Haast Pass highway, on the south side of the Okuru River and on the north side of the Turnbull River (Figs. 1-3). These are steep mountain rivers that transport erosion products from the southern Alps to the adjacent Tasman Sea. All of the rivers transport gravel bedload past the rangefront where the Alpine fault is located. Uplift of the southern Alps induces rapid river downcutting at the rangefront, leading to frequent abandonment of strath terraces. The trench sites are in all cases on abandoned strath terraces a few meters above the current floodplain.

Along this section of the fault in South Westland the trace is relatively simple and straight, although in detail it is composed of a number of short strands with both right and left stepovers of up to $20 \mathrm{~m}$, with strike ranging from $52^{\circ}$ to $57^{\circ}$, and with scarps ranging in height from 2 to $16 \mathrm{~m}$ (Norris et al., 2001).

Detailed topographic maps of the Haast and Okuru sites have been completed with real time kinematic (RTK) GPS equipment that returns horizontal and vertical positions to $0.02 \mathrm{~m}$ and $0.05 \mathrm{~m}$, respectively. We have used these data to quantify strike-slip and vertical displacement of terrace surfaces and risers and channels developed in the surfaces. Five trenches, two at the Haast and Okuru sites and one at the
Turnbull site, were excavated to expose displaced terrace deposits and to map the relationships among the faulted deposits. We also hoped to find material for radiocarbon dating, this being the main preexisting deficiency in paleoseismology investigations on the Alpine fault.

\section{Geomorphology and Stratigraphy}

In this section we describe geomorphology, stratigraphy, and stratigraphic implications for fault rupture events. A number of radiocarbon ages are displayed on trench logs. We discuss dating in a separate section where we highlight the challenges encountered with apparent recycling of material from one stratigraphic to younger units through scarp degradation processes.

\section{Haast Site}

The 300-m-long, 2-m-high recent trace of the Alpine fault on the south side of the Haast River has been known for many years (e.g., Wellman, 1953), where an $\approx 16$-m dextral displacement of a channel riser has been recorded (Figs. 3, 4). Beyond the clear, 300-m long trace, the fault extends into swampy terrain, and the trace is obscured for $\approx 5 \mathrm{~km}$, until it climbs onto older terrace surfaces for the remaining $3 \mathrm{~km}$ to the Okuru River (Fig. 1). Until we surveyed the 300-m section at the Haast River with RTK GPS, the low-amplitude channels had been observed but correlation had proven difficult. Now we are able, in concert with stratigraphy 


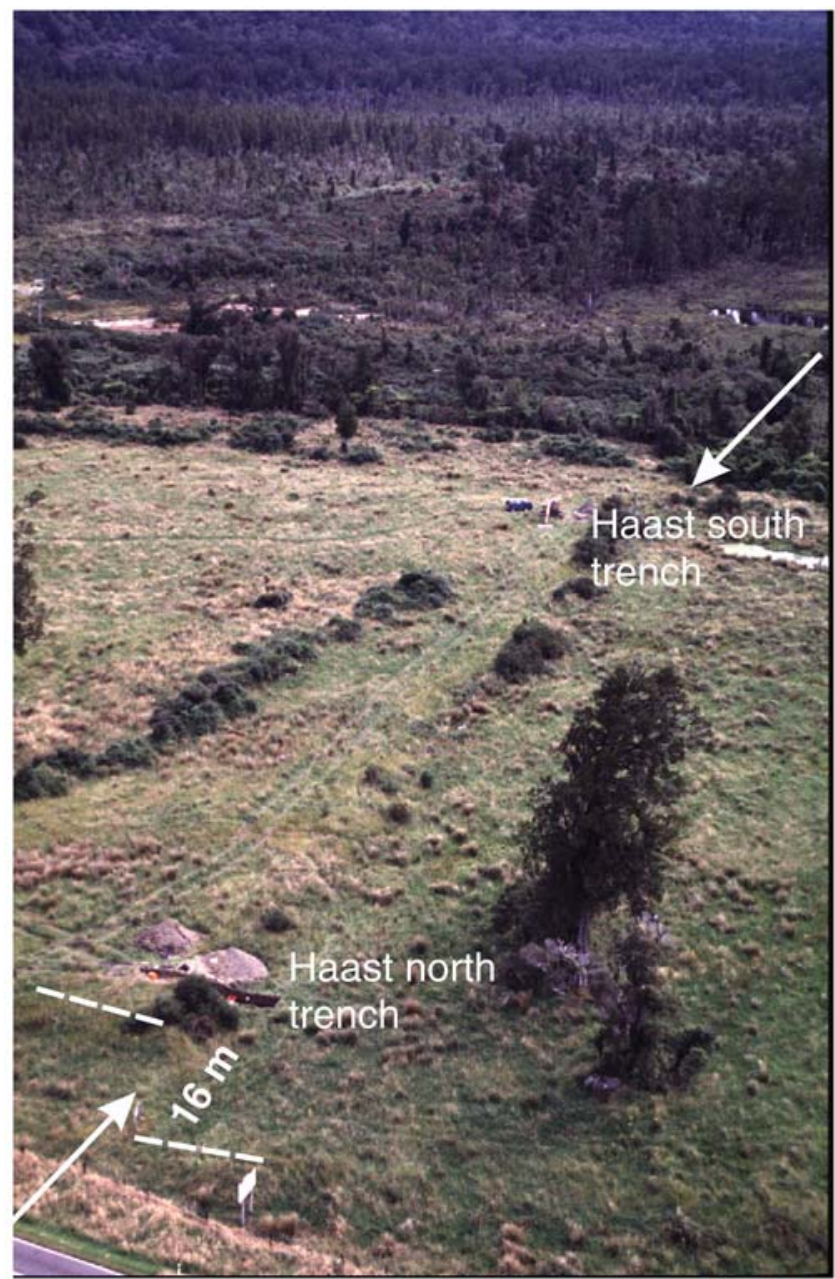

Figure 3. Aerial oblique photo of trace of the Alpine fault at the Haast site. The two trenches at the Haast site that are described and interpreted in this paper are identified, as is the prominent $16-\mathrm{m}$ dextral displacement of a terrace riser adjacent to the Haast Pass highway in the bottom left of the figure. The color version of this figure is available only in the electronic edition.

observed in two trenches at this locality (Figs. 3-7), to interpret successive displacement over the past circa $1300 \mathrm{yr}$.

In Figure 4 we show the present-day topography about the fault trace from the offset terrace riser for approximately $300 \mathrm{~m}$ to the southwest. Contouring at a $0.2-\mathrm{m}$ vertical interval has revealed the somewhat eroded scarp varying from 0.5 to $2.0 \mathrm{~m}$ in height, although we shall see that this is due, in part, to lateral displacement. A secondary scarp, that had not been recognized previously, is located about $60 \mathrm{~m}$ to the southeast and appears to have only vertical separation. It does not extend all the way across the terrace to the road. The topographic map also shows that three terrace levels (T1-T3) exist on both the upthrown (southeast) and downthrown (northwest) sides of the fault, with abandoned channels on the terrace surfaces (Fig. 3b). The most prominent riser is $1.0-1.2 \mathrm{~m}$ high to the southeast of the fault and separates T3 from T2. On the northwest side the riser is $0.6-1.0 \mathrm{~m}$ high and separates $\mathrm{T} 3$ from a higher terrace (T2). A second riser is not observed on the northwest side. The riser between $\mathrm{T} 2$ and $\mathrm{T} 1$ on the southeast side is about $0.8 \mathrm{~m}$ high.

The two trenches (Figs. 3, 4) were located on T1 and T2 terraces on the southeast (upthrown) side, and with unknown, indeterminate correlation with terraces on the northwest (downthrown) side. The well-known $\approx 16-\mathrm{m}$ dextral offset of the T2/T3 riser is immediately adjacent to the Haast north trench on the river side. Based on dextral topographic offsets elsewhere in South Westland, Berryman et al., (1992) and Cooper and Norris (1995) have interpreted the 16-m dextral offset as recording the past two surface-rupture events on the fault.

In Figure 5 we show two scarp-parallel profiles located about $10 \mathrm{~m}$ from the trace (Fig. 4), and match channels as piercing lines across the fault, using the previously observed single-event dextral offset value of $8 \mathrm{~m}$ as a guide. We find only a poor match for approximately $8 \mathrm{~m}$ of dextral offset, but a very good match is found at $18.7 \pm 2 \mathrm{~m}$. Therefore, we halve this amount and show the match of channels at $9.3 \mathrm{~m}$ dextral displacement as the best estimate for the last event. The reconstruction of channel-piercing lines at $18.7 \mathrm{~m}$ suggests the riser offset of $\approx 16 \mathrm{~m}$ has probably been trimmed back by $\approx 3 \mathrm{~m}$ when T3 was the active riverbed. Another good match of a channel occurs for dextral displacement of about $28 \pm 3 \mathrm{~m}$ (channel 1 of Fig. 6), indicating the third event may also have involved about $9 \mathrm{~m}$ of dextral displacement. We test the robustness and consistency of the assessment of singleevent displacement by similar evaluation of channel offsets at the Okuru locality, and by checking whether the number of events observed from stratigraphic evidence in the three localities is consistent with geomorphic evidence.

Logs of the two Haast trenches are presented in Figures 6 and 7. Both trenches had similar stratigraphic records, although the Haast south trench also had a record of successive liquefaction events, which provide essentially independent corroboration of the successive faulting events interpreted from the fault geometry itself. In Figure 6 we show the present-day configuration of deposits and progressive back-stripping of the surface-faulting for the Haast south trench. The other trenches, including Haast north, Okuru north, Okuru south, and Turnbull, are interpreted to contain the same sequence of events, and we show the stratigraphic level at which faulting occurred (event horizons $[\mathrm{EH}]$ ) on those logs.

The stratigraphy found in all of the trenches was similar, with basal alluvial gravel overlain by an alternating sequence of alluvial and/or colluvial in-fill on the northwest (downthrown) side with intervening weak soils characterized by weak brown coloration and increase in clay content. On the southeast (upthrown) side some exposures had a sequence of fine overbank alluvial deposits above the gravel alluvium, but in many cases the upthrown side has been degraded as a consequence of faulting and relative uplift. The similarity in the stratigraphic sequence observed in all trenches enables us to use a single-unit numbering system across all three sites. There are some variations in the sedimentary 


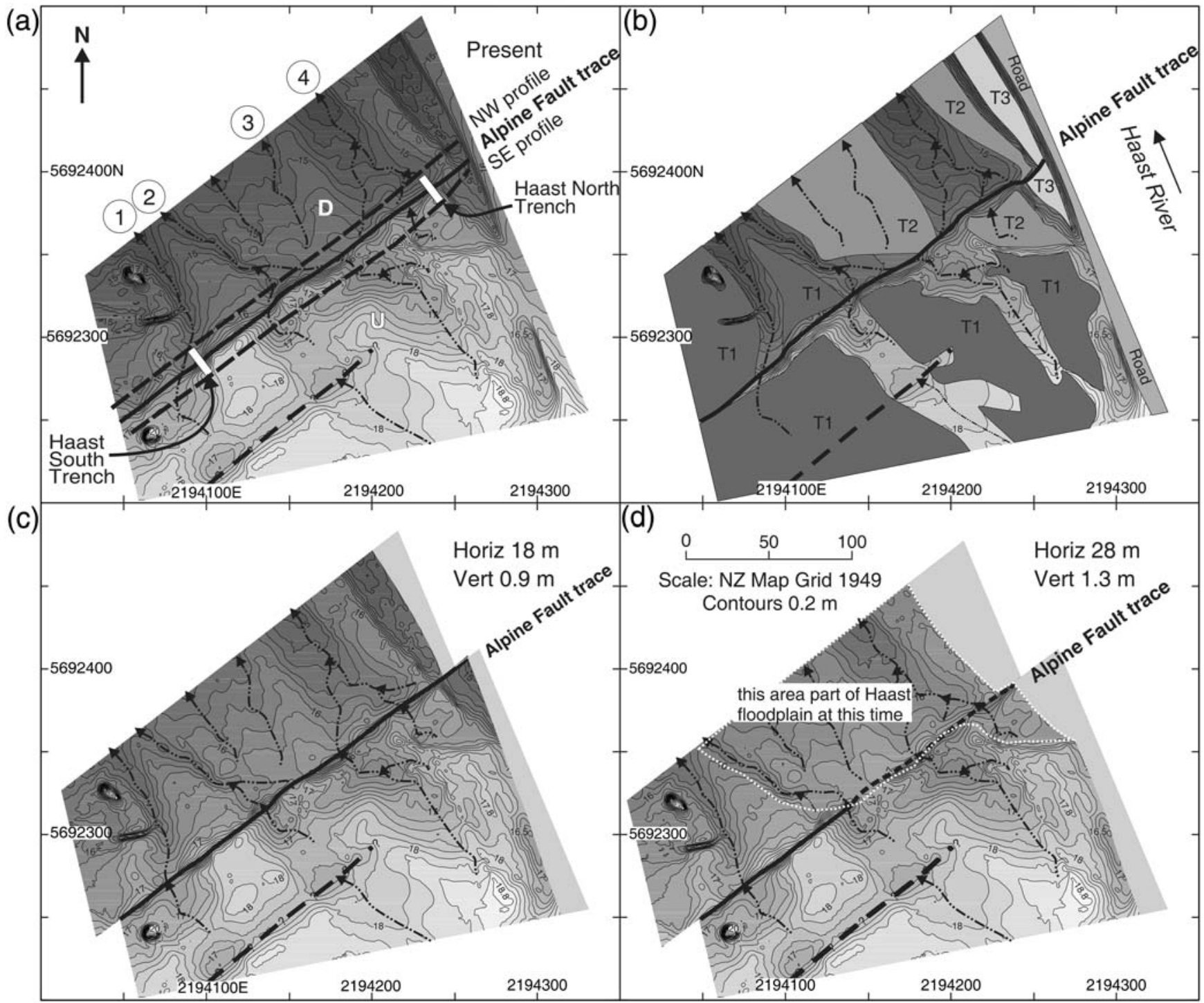

Figure 4. (a) Topographic map of the Haast site area derived from RTK GPS survey and the Kriging method at $1 \mathrm{~m}$ grid spacing, in the program SURFER7. Contour interval is $0.2 \mathrm{~m}$. Present-day topography, the location of two trenches, and channel pattern shown in A, along with the location of profiles across the terraces and channels shown in Figure 5. (b) Interpretation of topography in terms of terrace sequence. (c) Restoration of the terrace and channel pattern reversing $18 \mathrm{~m}$ (two events) of dextral displacement. (d) Restoration of the terrace and channel pattern reversing $28 \mathrm{~m}$ (three events) of dextral displacement. At this time the area to the north of the white dotted line was part of the active bed of the Haast River.

characteristics and thicknesses of units which are indicative of local conditions such as elevation above flood stage on each of the terraces, and to variation in vertical throw on the fault from site to site. In Table 1 we correlate the stratigraphic units among each of the trenches, and indicate the horizon when faulting has been identified in each of the trenches.

The Haast south trench records the following sequence of stratigraphic events (Fig. 6a):

- Deposition of alluvial gravel (unit 6g);

- Deposition of a sandy alluvial in-fill unit only on the northwest (downthrown) side of the fault as a consequence of the earliest faulting event recorded at this site (E3 of Table 1; unit 5i);
- Overbank facies alluvium deposited on both sides of the fault (units 5a, 5b, 5d). Unit 5d is a confined channel gravel deposit;

- A paleosol (unit 5p) developed in sandy alluvium on the overbank deposits, but is now only preserved on the northwest (downthrown) side because of later erosion;

- Unit 41 rests on the paleosol. It is interpreted as a liquefaction deposit derived from unit $5 \mathrm{i}$ and results from the surface-faulting event E2 of Table 1. A liquefaction feature is observed in the trench wall but is not connected directly with the surface sand unit. We expect that laterally along the fault the intrusive liquefaction feature broke the ground surface and in-filled a wide area of low ground on the northwest (downthrown) side of the fault; 


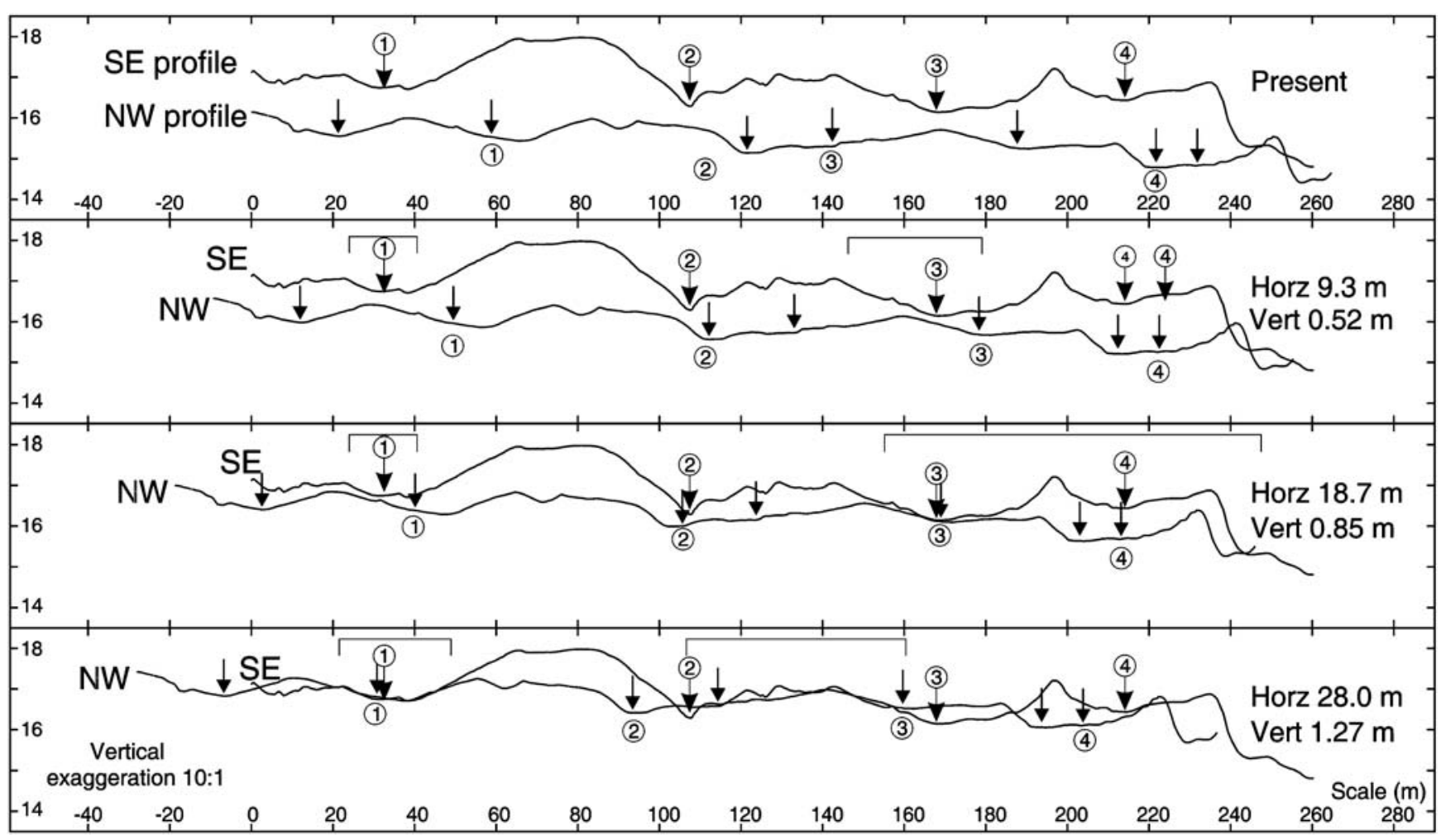

Figure 5. Reconstruction of offset channels along profile lines parallel to and within $10 \mathrm{~m}$ of the Alpine Fault as shown in Figure 4 . The channel piercing lines show a poor match for the most-recent event but good correlations for the second and third events at $18 \mathrm{~m}$ and $28 \mathrm{~m}$, respectively.

- An alluvial overbank deposit (unit 4i) occurs immediately above the liquefaction sand. It occurs only on the northwest (downthrown) side of the fault and is inferred to be an overbank deposit reentering the northwest side of the fault after a surface-displacement event;

- A paleosol (unit $4 \mathrm{p}$ ) has developed in the top of the unit $4 \mathrm{i}$;

- Unit 31 rests on the paleosol and is interpreted to be a liquefaction deposit resulting from surface-faulting event E1 of Table 1. Exposure of the liquefaction conduit, from unit $5 \mathrm{i}$ to the ground surface at this time, is clear. Unit 31 covers the paleosol and also infills fissures in the paleosol, which, along with juxtaposition of units at the fault, confirms that liquefaction occurs in association with fault rupture;

- A colluvial deposit (unit 3w) has formed as a consequence of this most recent faulting event, E1. The parent material for unit $3 w$ was unit 5 exposed in the scarp face at the time of fault rupture;

- Unit 2 is a subsoil developed in the top of unit $3 \mathrm{w}$ deposits on the northwest (downthrown) side of the fault, and in the top of the eroded unit 5 materials in the southeast (upthrown) side of the fault;

- A modern dark, organic, topsoil is below the present-day ground surface.

In Figure $6 \mathrm{~b}$ we show the progressive back-stripping of faulting and sedimentation events to eventually restore the site to an alluvial gravel floodplain of the Haast River. Liquefaction episodes coupled positions of paleosols as former ground surfaces is very helpful at this site as a basis for identifying event horizons and identifying former stable ground surfaces. The presence of weak paleosols with incipient B horizon development is indicative of a few hundred years of stability between faulting events. Restoration of faulting so that paleosols as former ground surfaces are restored indicates areas where material has been lost from the southeast (upthrown) side of the scarp and incorporated into colluvial units on the northwest (downthrown) side.

The Haast north trench is located close to the Haast River and is on a younger alluvial terrace than the Haast south trench (Figs. 3, 4). The following sequence of stratigraphic events is recognized (Fig. 7). They consist of one less package than the Haast south trench on the higher terrace, and the numbering of deposits reflects this (Table 1):

- Coarse gravel alluvium (unit 5g);

- Overbank gravelly sand (unit $4 d$ ) that is appreciably thicker on the northwest (downthrown) side of the fault;

- A sequence of thin sand and gravelly sand overbank deposits (units $4 \mathrm{a}, 4 \mathrm{~b}, 4 \mathrm{c}$ ) overlie unit $4 \mathrm{~d}$ on the southeast (upthrown) side of the fault. These units are not present on the northwest side, possibly as a consequence of strike-slip displacement on the fault;

- A thin wedge of material comprising a loose, coarse, sandy gravel (unit $4 \mathrm{w}$ ) is interpreted to be a scarp-derived colluvial unit resulting from degradation of unit 5 materials 
exposed in the scarp as a result of a faulting event. The coarse, sandy nature of this unit and the parent unit 5 is probably the reason for extensive degradation of the scarp after surface faulting (E2 of Table 1) and why the unit occurs on both sides of the fault plane;
- A silty overbank deposit (unit $3 i$ ) that is much thicker on the northwest (downthrown) side of the fault (inferred to be filling accommodation space created by fault rupture [E1 of Table 1] immediately prior to deposition of the unit);

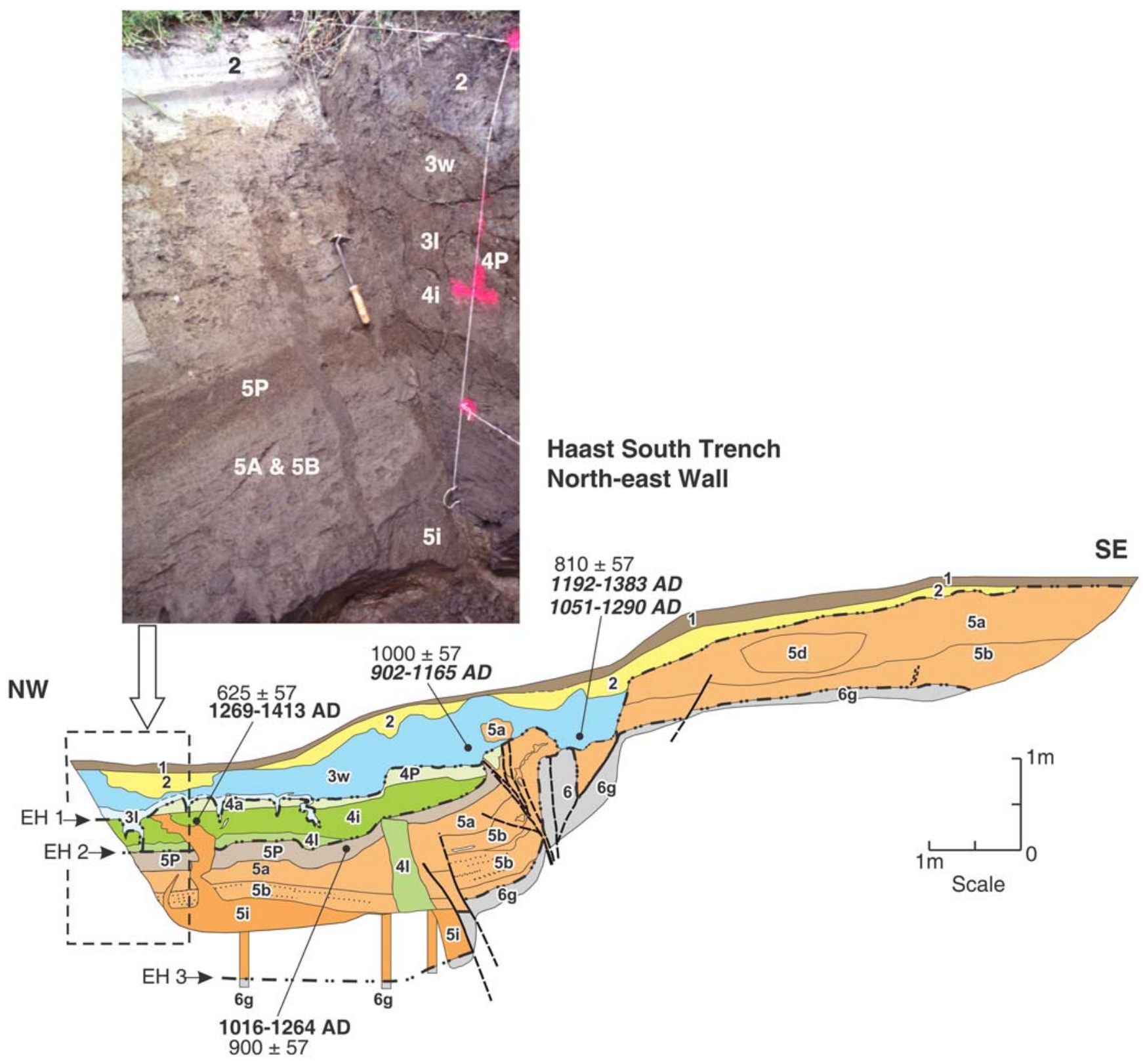

Figure 6. (a) Trench log of the northeast wall of the Haast south trench with units labeled according to the stratigraphic model developed in Table 1 and discussed in the text. Note the occurrence of liquefaction sand (l units) injection planes and their deposition on paleosols. The inset photo is from the northwestern end of the trench showing the field relations, fine alluvium (a and b units), paleosols ( $p$ units), (liquefaction sands (l units), in-fill units on the downthrown side of the fault as a consequence of newly created accommodation space (i units), and scarp-derived colluvial wedge units ( $\mathrm{w}$ units). Radiocarbon ages in normal type are consistent with stratigraphy and used to interpret the timing of past fault rupture events (Table 2), with calendric ages in bold. Anomalous ages for the stratigraphy are shown in italics, probably because of recycling of older material from the hanging wall. EH refers to event horizons, showing the stratigraphic level at which successive surface faulting occurred. (b) sequential restoration of the Haast south trench (starting with inferred relationships immediately event E1) indicating the likely architecture before and after the three faulting events identified. The sequential back-stripping of events removes units associated with faulting such as liquefaction units, in-fill events occupying newly created accommodation space, and scarp-derived colluvial wedges. Restoration of the trench log prior to the third event returns the site to a simple gravel-bed floodplain. The color version of this figure is available only in the electronic edition.

(Continued) 


\section{Haast South Trench North-east Wall}

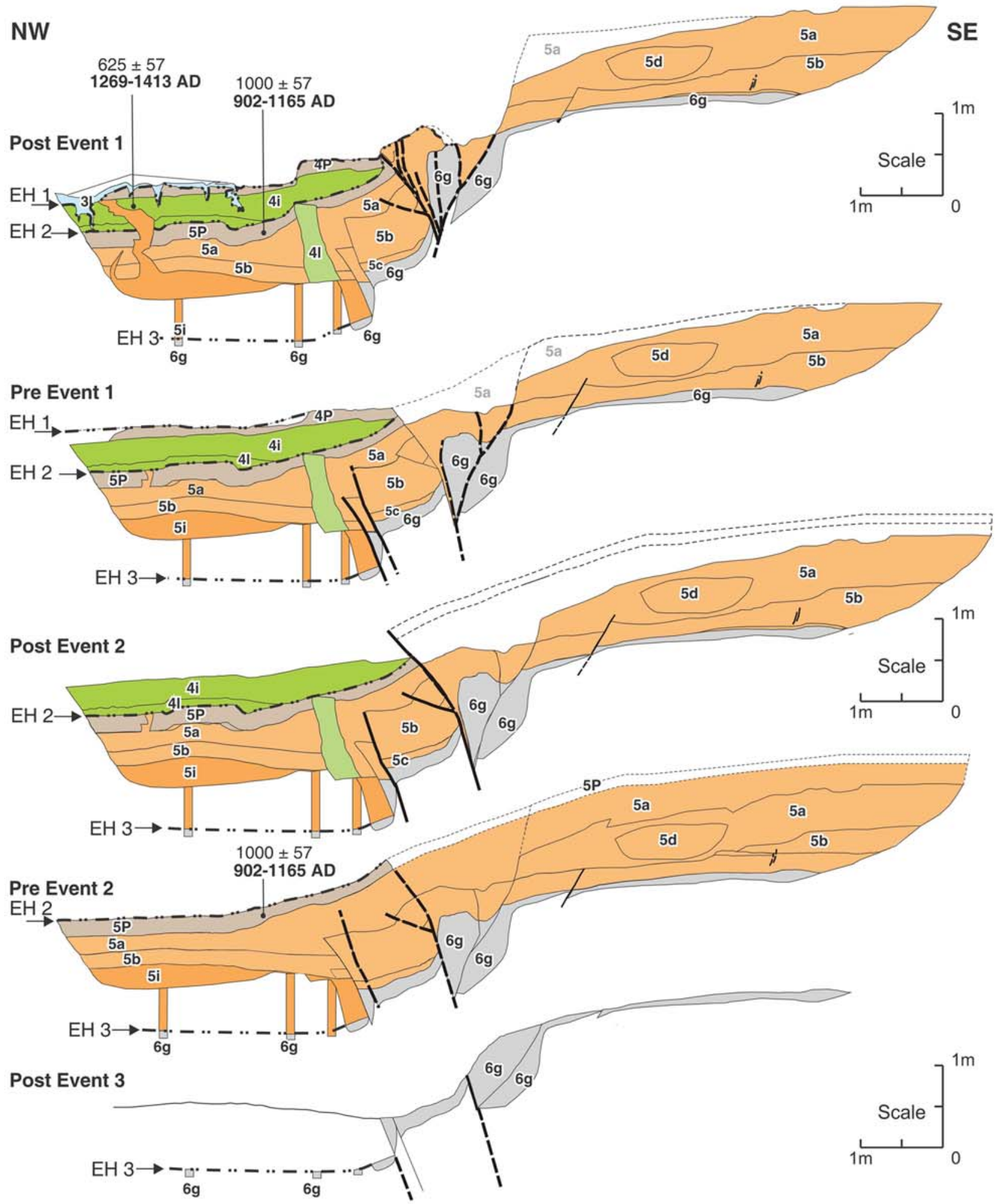

Pre Event 3

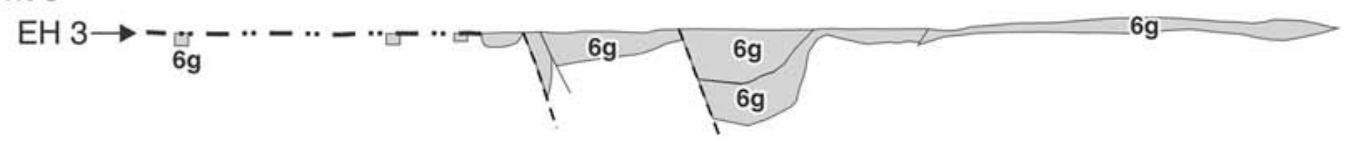

Figure 6. Continued. 


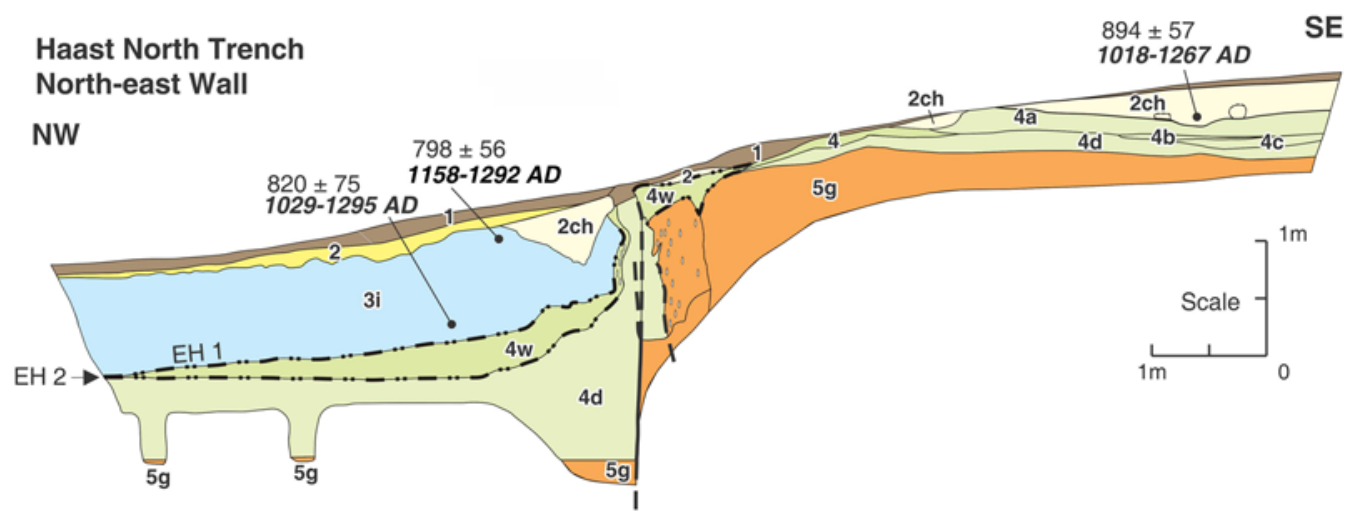

Figure 7. Trench log of the northeast wall of the Haast north trench. Units are the same as in Figure 6 and radiocarbon ages follow the same convention as in Figure 6; those in italics are anomalous, and those in normal type are consistent with stratigraphy and used to interpret the timing of past fault rupture events (Table 2). EH refers to event horizons, showing the stratigraphic level at which successive surface faulting occurred. Event 3 is not observed in this trench. The color version of this figure is available only in the electronic edition.

- Development of the modern topsoil (unit 1), a weak subsoil (unit 2) with more color than the underlying unit 3 , and small channel deposits (unit 2ch) on top of unit 3 deposits on the downthrown side of the fault, and into the eroded top of units 3 and 4 deposits on the upthrown side.

\section{Okuru Site}

The Okuru trench site is on the south bank of the Okuru River (Fig. 1). As with the Haast site, the presence of chan- nels on the terrace surface were noted previously, and some tentative correlations across the fault resulted in interpretations of successive, $\approx 8 \mathrm{~m}$ dextral displacements on the fault (e.g., Berryman et al., 1992). A high-resolution topographic map of the site recently became available via RTK GPS survey, but in the intervening period the area around the fault had been modified with an excavator in an attempt to improve drainage. Thus, the topographic map (Fig. 8a) contains several artificial mounds; this has made terrace and channel correlation more difficult.

Table 1

Correlation of Stratigraphic Units and Faulting Event Horizons among Trenches*

\begin{tabular}{|c|c|c|c|c|c|}
\hline Unit Groups & Haast North & Haast South & Okuru North & Okuru South & Turnbull \\
\hline Package 0 & - & - & - & - & 0 \\
\hline Package 1 & 1 & 1 & 1 & 1 & 1 \\
\hline \multirow[t]{2}{*}{ Package 2} & 2 & 2 & 2 & 2 & - \\
\hline & $2 \mathrm{ch}$ & - & $2 \mathrm{D}$ & - & - \\
\hline \multirow[t]{2}{*}{ Package 3} & - & $3 w$ & $3 w$ & - & - \\
\hline & $3 i$ & $3 l$ & - & - & - \\
\hline Event Horizon & E1 & E1 & E1 & NP & NP \\
\hline Package 4 & - & $4 p$ & - & - & - \\
\hline & - & - & $4 a$ & - & $4 \mathrm{c}$ \\
\hline & $4 w$ & $4 l \& 4 i$ & $4 w$ & $4 w \& 4 i$ & $4 i$ \\
\hline Event Horizon & E2 & E2 & E2 & E2 & E2 \\
\hline & $4 a, b, c, d$ & & & & \\
\hline & - & $5 p$ & $5 p$ & $5 p$ & $5 p$ \\
\hline \multirow{2}{*}{ Package 5} & - & $5 a, b$ & $5 \mathrm{a}, \mathrm{b}, \mathrm{c}, \mathrm{d}$ & $5 \mathrm{a}, \mathrm{b}, \mathrm{c}$ & - \\
\hline & $5 \mathrm{~g}$ & $5 i$ & $5 i$ & $5 i$ & $5 i$ \\
\hline Event Horizon & NP & E3 & E3 & E3 & E3 \\
\hline \multirow[t]{2}{*}{ Package 6} & - & - & - & - & $6 \mathrm{p}$ \\
\hline & - & $6 \mathrm{~g}$ & $6 \mathrm{~g}$ & $6 \mathrm{~g}$ & $6 \mathrm{~g}$ \\
\hline
\end{tabular}

*Units shown in italics are consequential of faulting. Dashes (-), unit/event is not present or is not recognized at this site. ch, channel; D, disturbed; w, scarp-derived colluvial wedge; $i$, in-fill unit in accommodation space; 1, liquefaction unit; p, paleosol; a, b, c, d, subdivided alluvial units; g, gravel. E1, E2, E3, faulting event horizon 1, 2, and 3 at this stratigraphic horizon. NP, not present (the particular event horizon has not been identified in the trench, because the appropriate unit does not occur [Haast north] or is not preserved [Okuru south and Turnbull]. 
Nevertheless, several channels on both sides of the fault and the $\approx 2$-m-tall riser at the forested edge of the faulted terrace sequence are clearly discernible. We recognize three principal terrace levels in the open fields on the south side of the river. The lowest terrace is at about $12-\mathrm{m}$ elevation (T1, Fig. 8b). The terrace is $1-2 \mathrm{~m}$ above normal river level (about 10-11 m elevation) and is not displaced by the fault. The next higher terrace (T2) is at about $14 \mathrm{~m}$ elevation on the southeast (upthrown) side of the fault and is at $12-13 \mathrm{~m}$ elevation on the northwest (downthrown) side (Fig. 9). Terrace 3 is at $14-15 \mathrm{~m}$ elevation on the southeast (upthrown) side and 13-13.5 $\mathrm{m}$ on the northwest (downthrown) side. Terrace 3 is trimmed on the southern side, lowering to a further remnant of $\mathrm{T} 2$ along the forest edge (Fig. $8 \mathrm{~b}$ ). The scarp therefore varies in elevation between 1 and $3 \mathrm{~m}$, depending on the juxtaposition of topography. The alternating

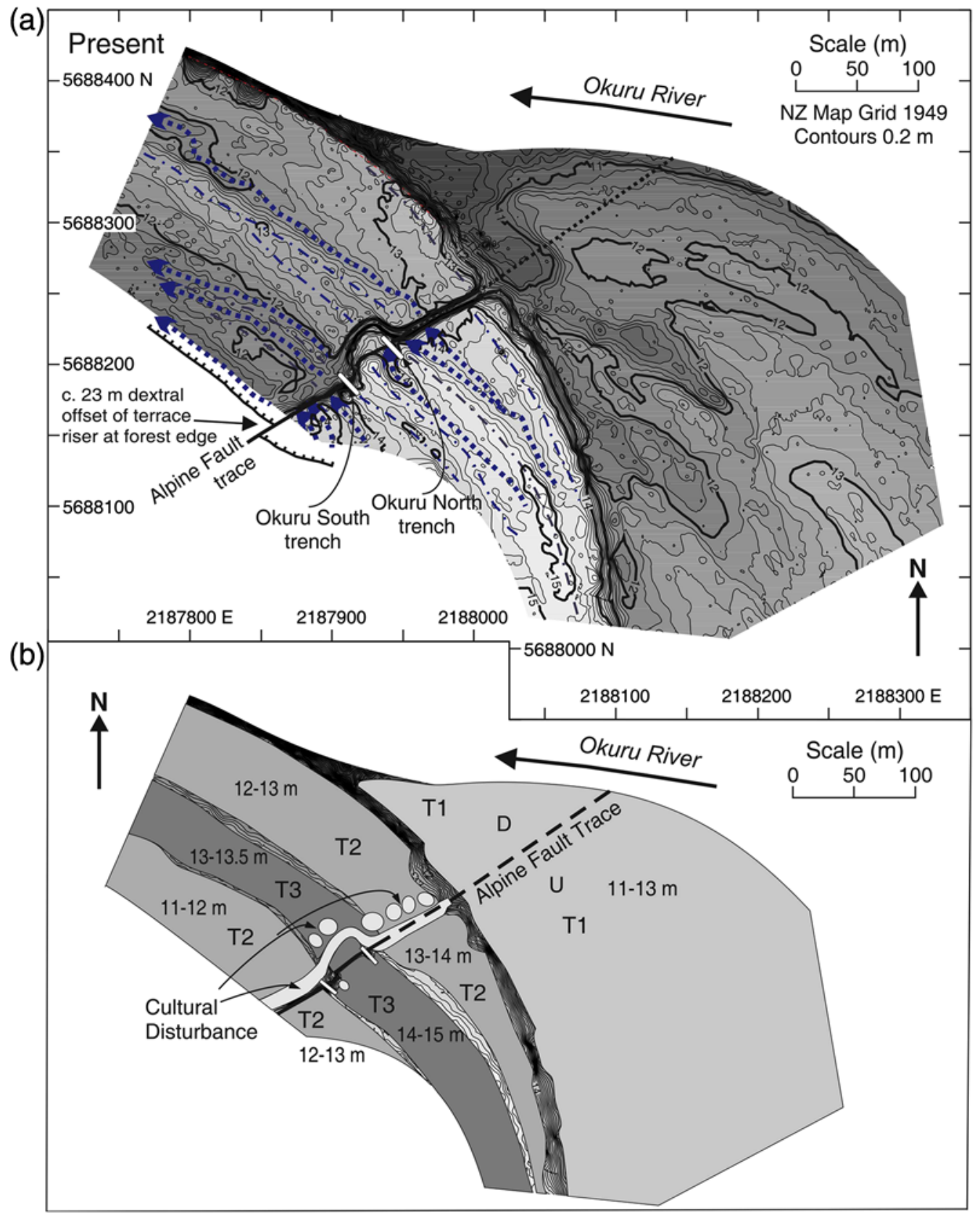

Figure 8. (a) Topographic map of the Okuru site area derived from RTK GPS survey and the Kriging method at 1-m grid spacing, in the program SURFER7. Contour interval is $0.2 \mathrm{~m}$, numerals are elevations in meters above mean sea level and gray scale indicates elevation (lighter gray scale corresponds to higher elevations). Present-day topography and the location of two trenches and channel pattern, along with the location of the 23-m dextral riser offset near the forest margin. (b) Interpretation of topography in terms of terrace sequence and their elevations (using modern Okuru River level of $10 \mathrm{~m}$ as the datum. The color version of this figure is available only in the electronic edition. 
sequence of ridges and channels has a pattern showing the terrace was formerly part of the Okuru River floodplain but is now above all but the largest floods. The channel pattern appears to relate to former flood channels, occupied when the river was probably forming the prominent riser between the faulted and unfaulted terrace, but before it had cut down to its present level. Channels and ridges on the faulted terrace are displaced, but not in a systematic fashion from the front of the terrace sequence to the back. Rather, it appears that the flood channels are on surfaces with only small vertical separation, but have been reoccupied at different times so that some channels record only the latest displacement while others record more events.

At about 7.5-m dextral displacement two channels become aligned, as does the riser at the front of the faulted terrace (Fig. 9a). There is significant uncertainty in measuring the displacement, largely because of disturbance of the topography close to the scarp. We therefore estimate the most recent displacement at the Okuru site involved $7.5 \pm 2 \mathrm{~m}$ of dextral displacement, in the same range as that estimated at the Haast site. At about $16 \pm 3 \mathrm{~m}$, approximately twice the smallest displacement, one channel and two ridges become aligned (Fig. 9b), and at about $23 \pm 3 \mathrm{~m}$ two channels and an intervening ridge are aligned (Fig. 9c). There is a tendency for channels and ridges farther from the existing floodplain to be aligned with increasing displacement. Thus, although the correlation of dextrally displaced topography has changed somewhat compared with earlier analysis of the site (cf. Berryman et al., 1992), the indication remains for approximately consistent single-event dextral displacement of $8 \pm 1 \mathrm{~m}$.

The topography we show in Figure 8 stops at the forest edge at the southern margin of the faulted terrace sequence. $\mathrm{An} \approx 2$-m high riser follows the forest margin, and although we cannot obtain a GPS-derived displacement measurement, we have used a total station electronic distance measuring instrument and tape to measure a dextral displacement of $23 \pm 3 \mathrm{~m}$ of this terrace riser (approximately located in Fig. 8a).

At the Okuru site we excavated two trenches, attempting to reconcile the number of events interpreted from geomorphology with the faulted stratigraphy observed in the trench, and to obtain samples for dating to constrain the age of past rupture events. The trench locations are shown in Figure 8a.

The Okuru trench sites are only $40 \mathrm{~m}$ apart, but the fault geometry was quite different in each, with a predominance of normal separation in the southern trench and reverse separation in the northern trench. In detail some changes exist in the fault geometry between the two sites, with a small left step located only a few meters northeast of the southern trench (Fig. 8b). The sequence of units observed in each trench is similar in general but differs in detail and in respect to the sequence of rupture of fault planes (Table 1). In the Okuru north trench the following sequence of stratigraphic events were observed (Fig. 10):

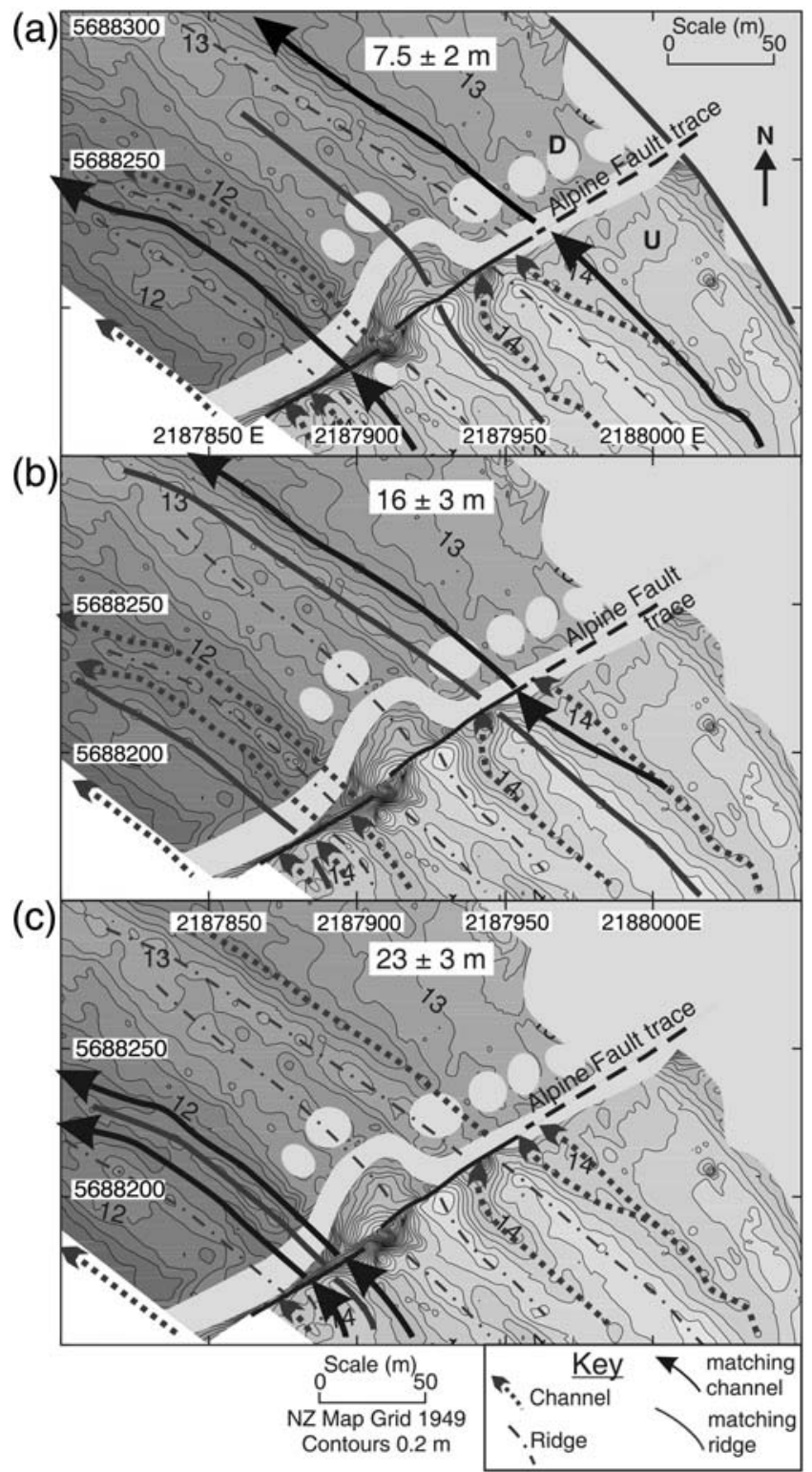

Figure 9. Reconstruction of offset terrace edges and stream channels at the Okuru site. The geomorphic surfaces and stream channels define piercing lines used to reconstruct the last three offsets on the Alpine Fault (A, B, and C). Numerals are elevations in meters above mean sea level and gray scale indicates elevation (lighter gray scale corresponds to higher elevations).

- Alluvial gravel (unit $6 \mathrm{~g}$ ) exposed as the lowermost unit in the trench represents the alluvial floodplain of the Okuru River;

- Unit $5 \mathrm{i}$ is a fine, alternating centimeter-decimeter scale, reverse-graded, sand and silt in-fill deposit that is only observed northwest of fault 3 . This unit was not observed between faults 3 and 4 , but could be below the bottom of the trench exposure. This unit does not occur on the southeast (upthrown) side of the fault, suggesting deposition in the accommodation space created by fault rupture (E3 of Table 1) involving some subsidence of the downthrown side of the fault, as observed at the Haast site; 


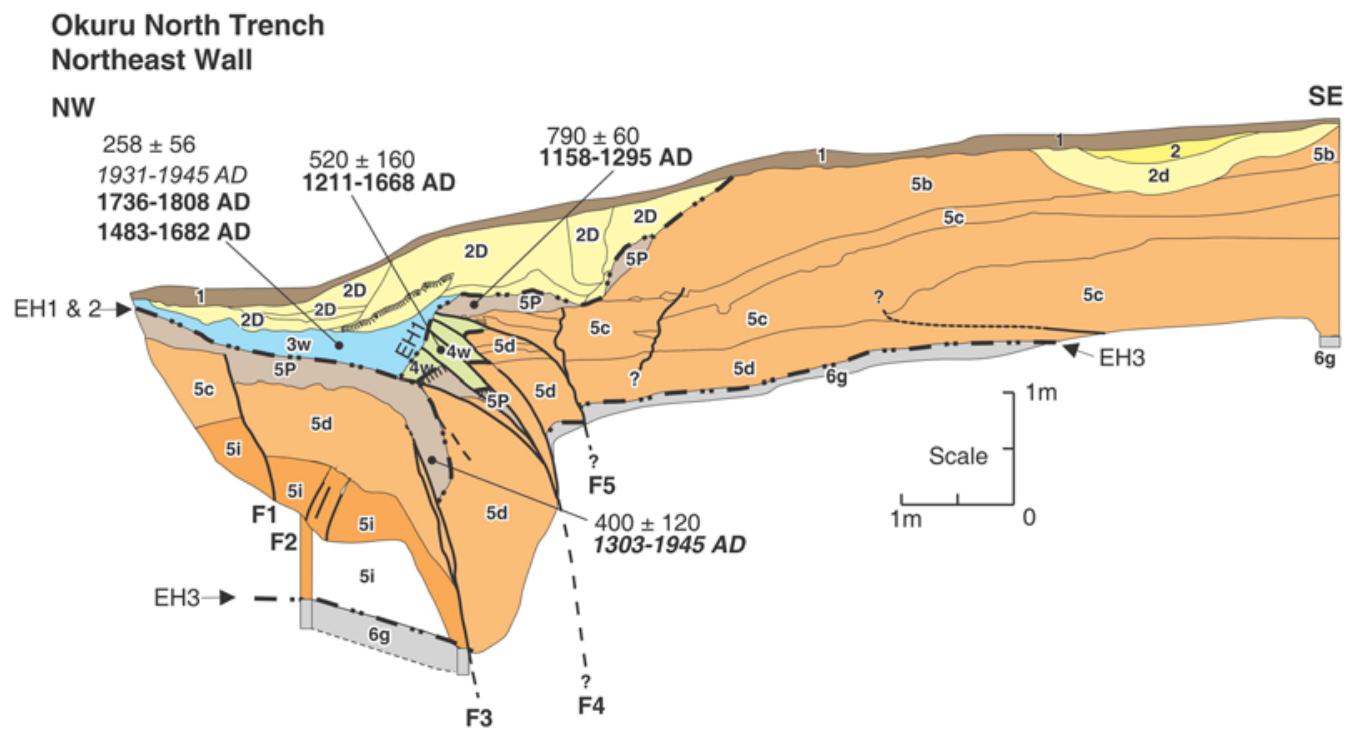

Figure 10. Trench log of the northeast wall of the Okuru north trench. Units are the same as in Figure 6 and radiocarbon ages follow the same convention as in Figure 6; those in italics are anomalous, and those in normal type are consistent with stratigraphy and used to interpret the timing of past fault rupture events (Table 2). Hachured lines mark paleosol horizons. EH refers to event horizons, showing the stratigraphic level at which successive surface faulting occurred. Note that EH2 is below unit $4 \mathrm{w}$ in the fault zone. The color version of this figure is available only in the electronic edition.

- Units $5 b$, c, and d are alluvial sand and silt units similar to unit $5 \mathrm{i}$, but found on both sides of the fault, probably representing flood overbank deposits;

- Unit $5 p$ is an olive brown, massive, clayey silt with a weakly developed vertical structure. The color, texture, and structure indicate a hiatus in alluvial deposition and development of a paleosol. This unit therefore represents a period of time coinciding with a stable local environment, having recovered from the prior fault disruption. Unit $5 p$ is disrupted in the trench exposure as a result of more recent faulting;

- Unit $4 \mathrm{w}$ overlies the $5 \mathrm{p}$ paleosol in the vicinity of fault 4 . The unit is an olive gray, massive, loose, fine sand with some patches of silty, fine sand. This unit is restricted in its distribution to the area around fault 4 . We interpret this unit as a colluvial wedge unit generated by faulting (E2 of Table 1) that dismembered the $5 \mathrm{p}$ paleosol. This unit is broken by strands of fault 4 ;

- Unit $3 w$ overlies unit $4 w$ in the vicinity of fault 4 , but is not broken by any of the faults. The unit is olive in color, massive, loose, and composed of slightly clayey silt and contains pods of gray, slightly sandy silt. We interpret this unit as a scarp-derived colluvial wedge formed as a consequence of the most recent fault rupture (E1 of Table 1);

- Unit 2D contains a diverse mixture of units, and most significantly mixed units of wood, silt, and sand. We interpret the collection of packages in unit 2 as resulting from disturbance associated with forest clearance and later farming activity. We cannot incorporate any of unit 2 and younger stratigraphy into the geologic interpretation. We also accept that the surface scarp of the fault at this locality is modified;
- Unit 1 is a modern topsoil comprising dark brown clayey silt with charcoal, wood, and abundant modern roots.

In the Okuru south trench (Fig. 11) the same general sequence of stratigraphic units and events were observed as in the Okuru north trench (Table 1). Therefore, we use the same nomenclature as for the Okuru north trench, but with subdivision as required. The following units were mapped:

- Alluvial gravel unit 6g;

- Unit 5 cannot be subdivided as easily as at the north trench site, but based on the unit thicknesses encountered in the auger hole, the alternating decimeter-bedded sand and clayey silt unit is about $1-\mathrm{m}$ thicker to the northwest (downthrown) side of the fault strands and most likely represents the same in-fill of accommodation space formed as a result of fault rupture (E3 of Table 1), as is observed in the Okuru north trench. In other respects, the units are very similar, including the reverse-graded tendency in the unit, and the presence of a paleosol (unit 5p) that has been faulted in a more recent event;

- Unit 4 has a small scarp-derived colluvial wedge subunit (4w) as in the north trench, and, to the west of fault 1, there is a weakly laminated, silty fine sand, apparently in-filling an accommodation space on the downthrown side of fault 1. We label this unit $4 \mathrm{i}$. A faulting event (E2 of Table 1) is inferred along the base of the $4 \mathrm{i}, 4 \mathrm{w}$ units. As well, there is a weakly bedded, silty fine sand (unit $4 \mathrm{a}$ ) deposited on top of the scarp-derived unit. This is different from the stratigraphy at the north trench, and perhaps indicates the presence of an overflow channel of the river cutting across the terrace sequence at this locality at that time; 


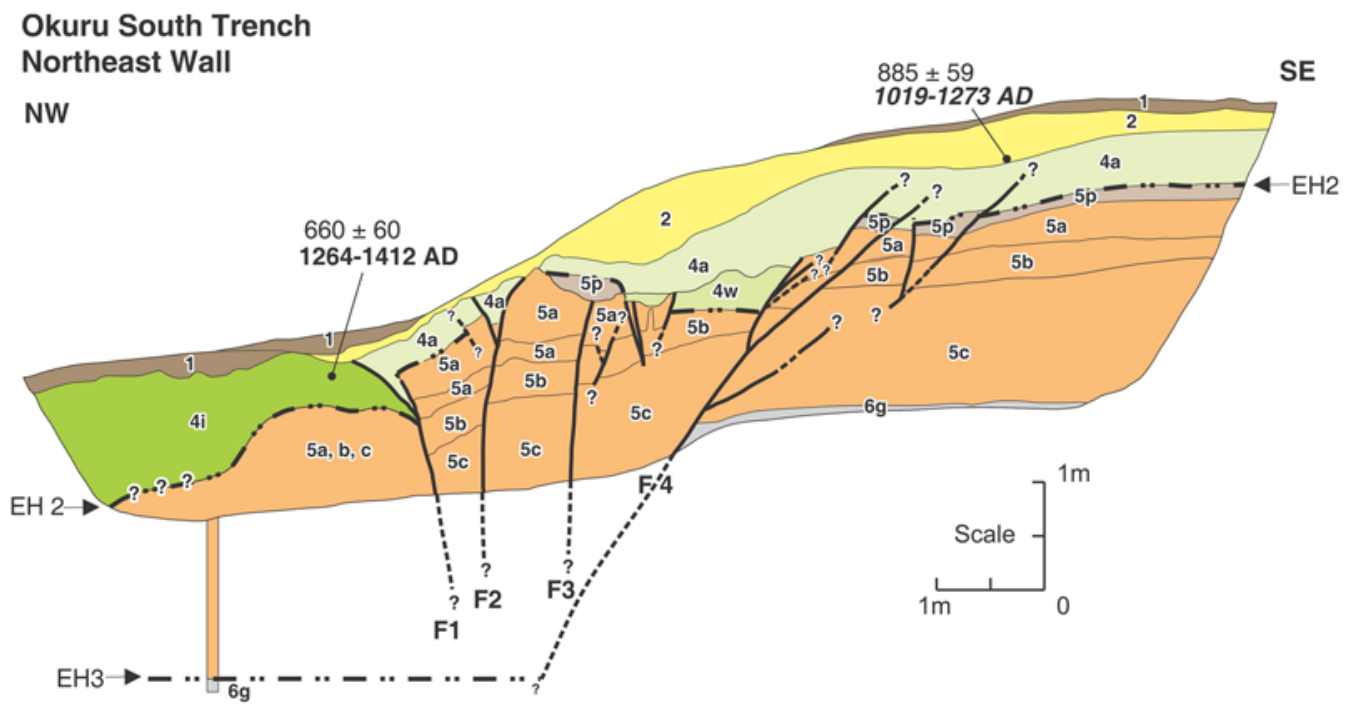

Figure 11. Trench log of the northeast wall of the Okuru South trench. Units are the same as in Figure 6 and radiocarbon ages follow the same convention as in Figure 6; those in italics are anomalous, and those in normal type are consistent with stratigraphy and used to interpret the timing of past fault rupture events (Table 2). EH refers to event horizons, showing the stratigraphic level at which successive surface faulting occurred. Event 1 is not observed in this trench. The color version of this figure is available only in the electronic edition.

- Unit 3 is missing from this trench exposure. Above unit 4 there appears to be a trench-wide unconformity upon which unit 2 was deposited;

- Unit 1 is composed of a thin, dark brown, clayey silt topsoil (unit 1a) with charcoal roots and wood, and a dark yellowish brown, clayey silt subsoil, again with charcoal and some roots (unit $1 \mathrm{~b}$ ).

\section{Turnbull Site}

A 22-m-long trench was excavated adjacent to the Turnbull power station access road, approximately $100 \mathrm{~m}$ north of the present river channel (Fig. 1). The scarp at this site trends $055^{\circ}$, and is about $1.5-\mathrm{m}$ high, upthrown to the southeast, but has been modified somewhat by construction of the adjacent road. Heavy forest covers the trace everywhere, except in the vicinity of the trench. The fault is manifest as a fan-shaped array of planes located at the southeast end of the trench, spanning a width of 2-3 m (Fig. 12). Upper terminations of fault planes occur at two distinct levels, one only affecting the lowermost paleosol (see the following discussion of stratigraphic events), and the other extending up to an unconformity that we interpret to be artificial, resulting from road construction. We cannot define the youngest episode(s) of faulting in the trench.

The stratigraphy exposed in the trench is similar to that found in the Okuru and Haast trenches with alluvial gravel overlain by overbank sand, overlain, particularly on the downthrown (northwest) side, by alternating overbank sand and paleosols (Fig. 12, Table 1). In addition to the stratigraphy observed in the trench, the stratigraphy of a wider area on the downthrown side of the fault was interpreted from a series of auger holes up to $105 \mathrm{~m}$ from the fault trace. This

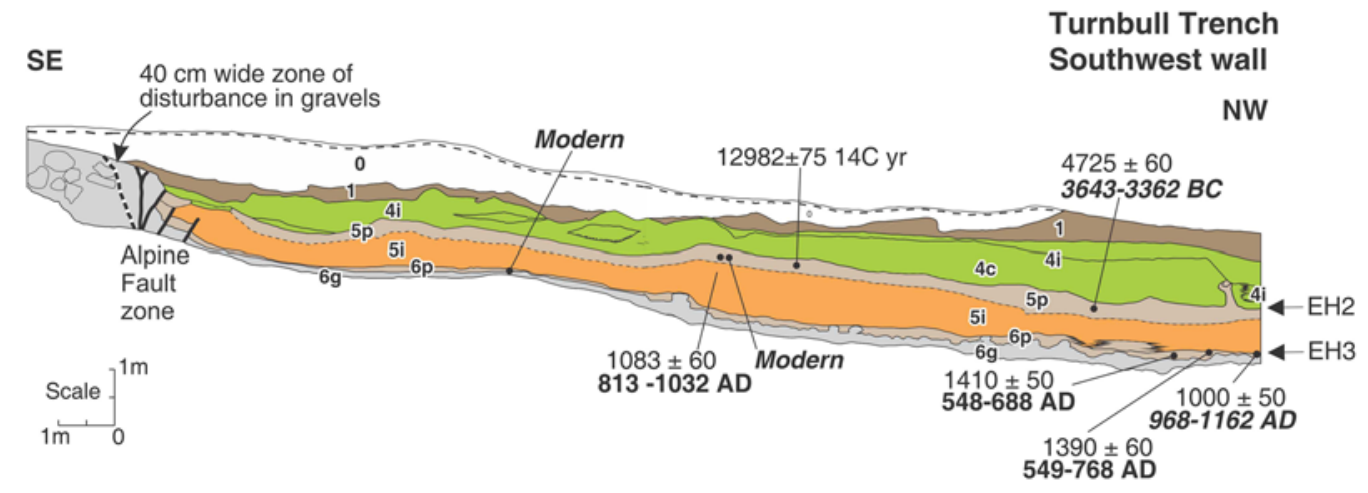

Figure 12. Trench log of the southwest wall of the Turnbull trench. Units are the same as in Figure 6, and radiocarbon ages follow the same convention as in Figure 6; those in italics are anomalous, and those in normal type are consistent with stratigraphy and used to interpret the timing of past fault rupture events (Table 2). Event 1 is not observed in this trench. The color version of this figure is available only in the electronic edition. 
revealed the dimension of the alluvial in-fill on the downthrown side of the fault and suggests tectonic downwarping forming accommodation space following successive rupture events extended to about $85 \mathrm{~m}$ from the scarp. It is likely that accommodation space of similar dimensions is also present at the Haast and Okuru sites.

The sequence of stratigraphic events recognized in this trench is as follows (Fig. 12):

- Unit $6 \mathrm{~g}$ is an alluvial gravel exposed as the lowermost unit in the trench and represents the alluvial floodplain of the Turnbull River;

- A weak soil (unit $6 p$ ) formed on the alluvial gravel, indicating the river had abandoned this location. Abandonment may have been initiated by fault rupture causing river downcutting, such as has been interpreted from the Haast and Okuru sites, but here there is no structural or stratigraphic evidence for this;

- Soil formation was terminated by arrival of a sanddominated alluvial in-fill (unit 5i). This unit is only on the northwest (downthrown) side of the fault and is inferred to occur after surface rupture in event 3 (Table 1). The unit can be traced up to $85 \mathrm{~m}$ from the scarp;

- A weak soil (paleosol 5p) formed on in-fill sand unit 5i;

- In-fill sand (unit 4i) was deposited on paleosol unit 5p, filling accommodation space created by surface rupture in event 2 (Table 1). Near the western end of the trench, the clayey paleosol of unit $5 p$ is squeezed up into unit $4 \mathrm{i}$. This may be indicative of event 1 in the trench, although other stratigraphic evidence has been removed by recent bulldozing;

- A channel fill deposit (unit 4c), resembling a back-water flood channel and swamp on its margins, is interbedded with sand and clay, and near its center a fine, gravelly sand. The geometry of this unit suggests scarp-parallel deposition of units in the lowest part of the down-warped accommodation space;

- An organically rich, gray, silty sand above the channel fill unit forms the surface soil away from the scarp, but close to the scarp is buried by a massive, matrix-supported cobbly sand that we interpret to be an artificial fill deposit (unit 0) related to road formation. Thus, the organically rich, gray, silty sand represents the modern topsoil (unit 1).

Compared with the stratigraphy found in other fault trenches, we have not observed a paleosol on unit 4 deposits (unit $4 p$ ) or unit 3 alluvial or colluvial units in the Turnbull trench. It may be that the modern soil is a composite of both units 1 and $4 \mathrm{p}$. Road construction in the vicinity of the scarp has obliterated the possibility of observing scarp-derived units in close proximity to the fault plane.

\section{Summary of Criteria for the Identification of Surface-Faulting Events}

In the description of stratigraphy in each of the trenches, some introduction to the identification of surface-faulting events has occurred. The manifestations of faulting take a variety of forms, and it is the joint or multiple indicators for faulting at particular horizons that provide confidence in the interpretations (see Table 1 for summary). Key criteria for faulting are:

- Fault juxtaposition of contrasting units and identification of upper terminations of fault strands. Both aspects of this criterion have been used in this paper, and with the faulting generally being distributed across several planes, upper terminations are particularly evident (e.g., Haast south and Okuru north trenches; Figs. 6, 10). These criteria are important in the definition of each of the three surface-faulting events.

- The presence of liquefaction sands adjacent to the fault at the Haast south trench (Fig. 6) is not a direct observation of rupture of the Alpine fault because a possibility exists that successive distant earthquakes triggered the liquefaction. However, the colocation of the liquefaction and the Alpine fault and other corroborative stratigraphic criteria make the observed liquefaction features a very probable indicator of the fault rupture events. The observation of the sand dike and the sand boil on the former ground surface as marked by paleosols provides very good stratigraphic definition of the E2 and E3 surface-faulting events.

- The presence of thicker, fine-grained, overbank flood deposits on the downthrown side of the fault is interpreted to be evidence for preceding land surface change and opportunity for sedimentation in newly formed accommodation space. These deposits are common in all five trenches and are important in identifying surface-faulting event 1 in all except the Haast north trench, and event 2 in the Haast south, Okuru south, and Turnbull trenches (Table 1; Figs. 6, 7, 11, 12).

- The presence of wedge-shaped colluvial units thinning away from the surface scarp and fault plane are often interpreted as forming consequent to surface fault rupture and represent local erosion and deposition by surface processes active in reestablishing landscape stability (see McCalpin, 1996 for review). Scarp-derived colluvial wedges are recognized in all except the Turnbull trench and are important in constraining events 1,2 , and 3 (Table 1).

\section{Dating of Surface-Faulting Events}

Three faulting events are recognized within three of the five trenches (Table 1). The Haast north trench site is on a lower terrace than other localities, and only records two events since the abandonment of the alluvial surface associated with unit $6 \mathrm{~g}$. Surface modification at the Turnbull trench site appears to have removed evidence of the most recent event. The oldest faulting event at both the Haast south and both Okuru sites occurred immediately prior to, and probably induced, abandonment of equivalent river flood- 
plains at both sites. At the Haast south trench the fault displacement resulted in deposition of a channel-fill sand unit on the downthrown side of the fault. Closely spaced auguring to define the margin of the buried channel deposit, which was partly exposed crossing the southern trench, indicates a total dextral offset of $25 \pm 4 \mathrm{~m}$ (the $\approx 28 \mathrm{~m}$ dextral offset of channel 1 of Fig. 6 is the surface expression of the displacement). The riser at the back of the T2 terrace at Okuru is dextrally displaced by $23 \pm 3 \mathrm{~m}$. This represents the cumulative dextral displacement in the three events recorded in the stratigraphy at both the Haast and Okuru sites.

Constraints on the times when surface ruptures occurred has proven problematical. At the Turnbull trench many organic samples were collected and dated, but two from unit 5P are inferred to have been contaminated by a source of old carbon because the late Pleistocene or middle Holocene age is inconsistent with other ages, and others appear to be tree root material growing down from higher and younger horizons (Table 2). Two wood samples and bark from tree fern obtained from paleosols in the Turnbull trench are useful in providing maximum ages for events 2 and 3 (Table 2). In the Haast and Okuru trenches the only readily dateable material found were small, black, kidney-shaped seeds that occur extensively in the overbank silt and sand deposits, within paleosols developed in these units, and sparsely within colluvial wedge units. The seeds are from grasses that grew on successive paleo-ground surfaces at or perhaps a little upstream of the trenching sites. Two samples from the unit $6 p$ paleosol on the package $6 \mathrm{~g}$ gravels at Turnbull trench predate event 3 (A.D. 549-768 and A.D. 548-688, with $2 \sigma$ uncertainties), placing a constraint on event 3 as younger than circa A.D. 550. The oldest date of the package 5 paleosol unit comes from the Turnbull site; this places a minimum age constraint on event 3 as older than A.D. 813. Using these results in the OxCal program (Bronk-Ramsey, 2010) provides a best-estimate of the timing of event 3 at A.D. 688-1066 (Fig. 13, Table 2).

Three accelerator mass spectrometry radiocarbon dates of separated seeds from the package 5 paleosol predate event 2 (A.D. 813-1032, A.D. 1016-1264, and A.D. 11581295), two in-fill units (postfaulting) from package 4 at the Okuru south and Haast north trenches (A.D. 12641412 and A.D. 1269-1413), and a less precise colluvial wedge age (A.D. 1211-1668) place minimum age constraints on event 2 (Table 2). Using these ages on the OxCal program provides an age range for event 2 of A.D. 12111371 (Fig. 13, Table 2).

The age of the most recent event is poorly constrained because of the wide possible age range of the single sample from the Okuru north trench that postdates the event. This sample from a package 3 colluvial wedge has an age of A.D. 1483-1682, plus A.D. 1736-1808, plus A.D. 1931-1945 (Table 2). We can limit the range somewhat by a historical constraint of no surface fault rupture since European settlement for which we use a date of A.D. 1840. Thus, the event is post circa A.D. 1483 and is older than A.D. 1840 from

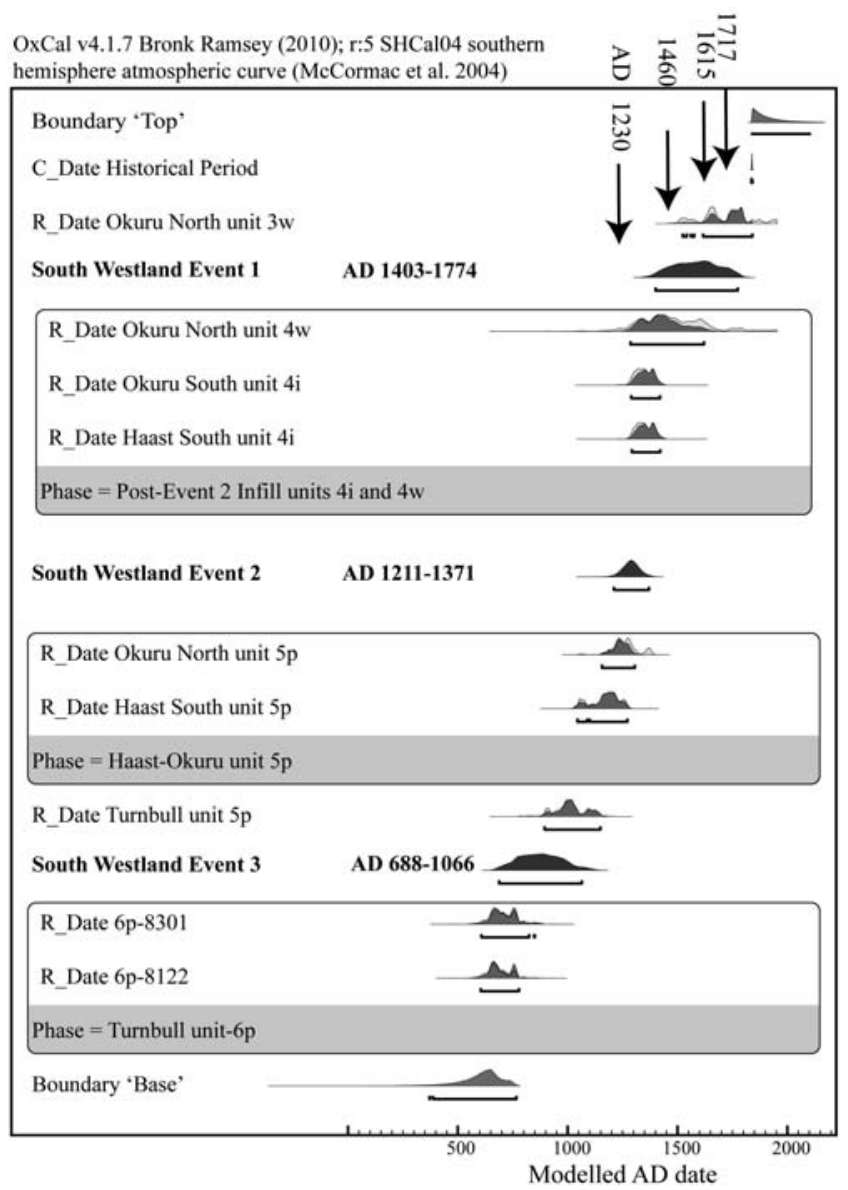

Figure 13. OxCal stratigraphic ordering plot for sites on the Alpine fault in South Westland. Shaded regions represent calibrated age distributions (probability density functions [PDFs]) for radiocarbon dates and combinations of radiocarbon dates (shown by Phases). Prior age distributions are shown by light shaded PDFs; medium shaded PDFs represent posterior (shaved) radiocarbon age distributions. Dark colored PDFs show the age distributions of the three paleoseismic events on the fault. Ages shown at top right with arrows are estimates for the timing of recent ruptures on the Alpine fault from Wells and Goff (2007).

historical records. The OxCal program indicates an age range of A.D. 1403-1774 for the most recent, event 1 .

\section{Discussion}

Fault trench excavations at Haast, Okuru, and Turnbull River localities and radiocarbon dating of materials at these sites indicate that three, large-to-great earthquakes, each with $8-9 \mathrm{~m}$ of dextral displacement and about $1 \mathrm{~m}$ of vertical displacement, have occurred in the Haast area since circa A.D. 688. The interpretation of three events is supported by evidence for three geomorphic displacements of $8-9 \mathrm{~m}$ in a total of $25 \pm 3 \mathrm{~m}$ dextral displacement, stratigraphic units that fill space created by successive surface-faulting events and successive liquefaction layers expelled to the paleoground surface. If there were additional surface-faulting events, their surface expression and stratigraphic signature 


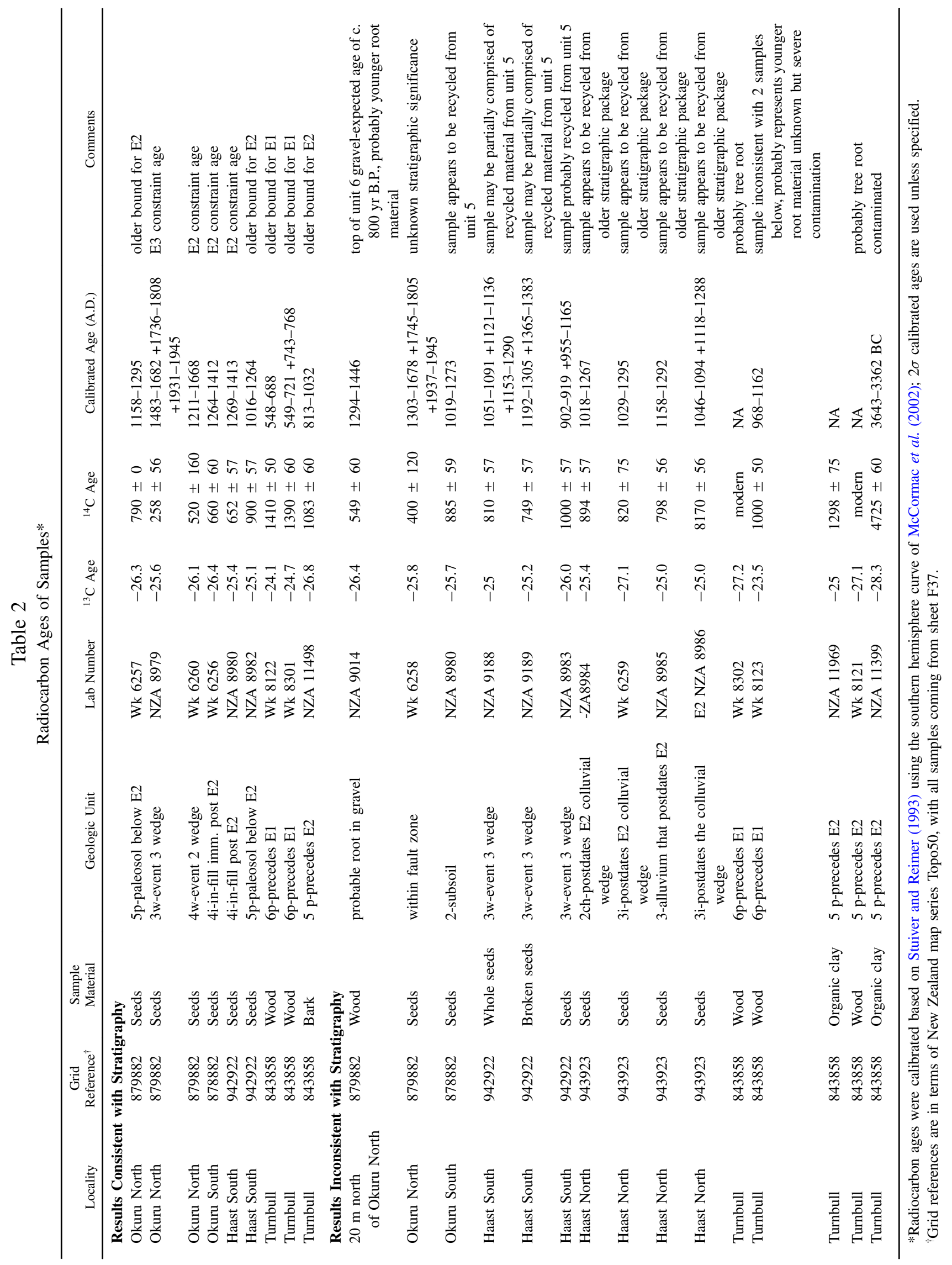


must be smaller than the $\approx 100$-mm resolution of piercing points exposed in trenches or $\approx 0.5 \mathrm{~m}$ of geomorphic displacement. We do not see any evidence in the stratigraphy of five trenches at three separate site for such events, but we cannot categorically rule them out.

Because the observed single-event displacement is 8-9 $\mathrm{m}$, we expect that each of the three surface-rupturing earthquakes observed at Haast involved rupture of several hundred kilometers of the Alpine fault, possibly involving an offshore section as proposed by Barnes et al. (2005), and much of the south and central Westland fault sections. We tentatively interpret the most recent event (event 1) occurred in circa A.D. 1717 (within the modeled OxCal range of A.D. 1403-1774), because of off-fault data along the southern section of the fault such as tree growth anomalies (Cooper and Norris, 1990; Wells et al., 1998), and major dunebuilding episodes (Wells and Goff, 2007). The proposed A.D. 1717 age is preferred rather than the slightly older circa A.D. $1615 \pm 10$ event that has been widely identified on the northern Alpine fault (Yetton, 1998), because landscape impacts of the circa A.D. $1615 \pm 10$ event in South Westland are not strong (Wells and Goff, 2007).

Event 2 at Haast occurred in the interval A.D. 1211-1371, which would suggest correlation with a major landscape change event in about A.D. $1230 \pm 50$ (Wells and Goff, 2007). No older major landscape change events have been dated in South Westland, so our on-fault age determination of A.D. $688-1066$ is the best estimate for the age of event 3 on the southern section(s) of the Alpine fault.

The on-fault data presented in this paper support only three surface-faulting events in the Haast area since circa A.D. 700. So what do the additional widespread landscape change events reported by Wells and Goff (2007) from dispersed locations adjacent to the Alpine fault at A.D. 1826, circa A.D. 1460, and circa A.D. 1615 represent? Most of the off-fault information on earthquake occurrence stems from episodic and widespread evidence for slope instability in the Southern Alps and rapid sedimentation pulses seen as aggradation terraces, landslides, forest cohort development, and coastal progradation events. Earthquake shaking generally extends over a much larger area than the surface fault rupture, and this provides the most obvious reconciliation between on-fault and off-fault earthquake information. The A.D. 1826 earthquake may have been a subduction event in the Fiordland subduction zone (Downes et al., 2005), while the circa A.D. 1615 event is related to rupture of the northern section of the Alpine fault (Yetton, 1998). The circa A.D. 1460 event has not been identified in any on-fault record, so it may be related to an earthquake that occurred within the southern Alps and not on the Alpine fault.

Accepting the long-term average horizontal slip rate of $23 \pm 2 \mathrm{~mm} / \mathrm{yr}$ (Sutherland et al., 2006) and $\approx 8-9 \mathrm{~m}$ single-event displacement for the southern, on-land section of the fault, this would suggest an average recurrence interval of $369+59 /-49$ years. The paleoseismic data we have developed from the Haast area indicate intervals of 380-
580 years between events 1 and 2, and 440-540 years between events 2 and 3, averaging 485 years, with an elapsed time of circa 295 years (in A.D. 2011) since the most recent event. The discrepancies between average recurrence and the last two intervals from on-fault data may be considered in several ways: (i) the fault does not rupture in periodic fashion, such that the last two intervals are about 100 years longer than the long-term average; (ii) not all of the strain was released in the last event and there is a surface slip deficit accumulating; (iii) the average horizontal slip rate of $23 \pm 2 \mathrm{~mm} / \mathrm{yr}$ established for the section of the fault about $50-120 \mathrm{~km}$ southwest of Haast is a little higher than actually occurs in the Haast area; or (iv) there is significant distributed faulting or off-fault deformation not currently identified as coseismic. The observed single-event horizontal displacement of 8-9 $\mathrm{m}$ and recurrence interval average of 485 years can be reconciled if the local strike-slip rate on the fault were $\approx 17-18 \mathrm{~mm} / \mathrm{yr}$, or average horizontal displacement per event was about $11 \mathrm{~m}$, or many combinations of the two.

At the San Andreas fault, Thatcher and Lisowski (1987) and Salyards et al. (1992) have reported shear deformation, up to $40 \mathrm{~m}$ from the fault, that has contributed significantly to the coseismic displacement of the 1906 rupture, and to coseismic displacements at the Pallet Creek locality. Similarly, deformation over a zone at least $100-\mathrm{m}$ wide has been observed along the Greendale fault, which has been documented in the immediate postrupture period following the September 2010 Darfield earthquake in the Canterbury region of New Zealand (Quigley et al., 2012). Perhaps the difference between 8-9-m dextral displacement observed at the Alpine fault trace and the required $11 \mathrm{~m}$ to account for the long-term slip rate and recent recurrence intervals may be accomplished by distributed shear adjacent to the fault trace. The pattern of braid channels on the terrace surfaces at the fault traces at Haast, Okuru, and Turnbull Rivers do not have sufficient resolution to detect this amplitude of possible distributed shear.

\section{Conclusion}

We interpret simultaneous terrace formation and initial rupture of terrace gravel at Haast, Okuru, and Turnbull localities at about A.D. $700-800$ to be due to the vertical component of displacement in a major surface-rupturing earthquake. The date of the penultimate event is probably about A.D. $1230 \pm 50$. The most recent event is consistent with circa A.D. 1717, the same as published dates of the last event at John O'Groats River (Cooper and Norris, 1990). The last three ruptures on the southern section of the Alpine fault occurred with an average recurrence interval of about 485 years. Each was associated with $\approx 8-9 \mathrm{~m}$ strike-slip and up to $1 \mathrm{~m}$ dip-slip displacement.

The results of this study indicate the recurrence of great earthquakes on the southern section of the Alpine fault may be longer than the 200-300 years previously considered, and may, on average, be as long as 480 years. The consequences 
of this scenario are that a large-to-great earthquake is not imminent on the fault with its circa 295-year elapsed time. If the dextral slip rate of $23+2 \mathrm{~mm} / \mathrm{yr}$ on the southern section of the Alpine fault is correct, then strike-slip motion in each surface rupture, perhaps across a broader deformation zone than is currently recognized, may average $11 \mathrm{~m}$.

\section{Data and Resources}

All data used in this paper are observations of the authors or came from published sources listed in the references. The OxCal program developed by Bronk-Ramsey (2010) (http://c14.arch.ox.ac.uk, last accessed January 2011) was used in developing the earthquake event chronology.

\section{Acknowledgments}

The authors acknowledge the assistance from local landowners, particularly Kerry Eggling, colleagues Dion Matheson, Kirby McLeod, and Heather Campbell for support in the field, and Nicola Litchfield for early versions of the graphics. Nicola Litchfield and Russ van Dissen provided valuable review comments on an earlier draft, and journal reviews by Tim Little and Bill Bull have added clarity to the interpretations presented.

\section{References}

Barnes, P. (2009). Postglacial (after $20 \mathrm{ka}$ ) dextral slip rate of the offshore Alpine fault, New Zealand, Geol., doi 10.1130/G24764A.1.

Barnes, P., R. Sutherland, and J. Delteil (2005). Strike-slip structure and sedimentary basins of the southern Alpine fault, Fiordland, New Zealand, Geol. Soc. Am. Bull. 117, 411-435.

Beavan, J., and J. Haines (2001). Contemporary horizontal velocity and strain rate fields of the Pacific-Australian plate boundary zone through New Zealand, J. Geophys. Res. 106, 741-770.

Berryman, K. R., S. Beanland, A. F. Cooper, H. N. C. Cutten, R. J. Norris, and P. R. Wood (1992). The Alpine fault, New Zealand: Variation in Quaternary structural style and geomorphic expression, Annal. Tect. 6, supplement, 126-163.

Berryman, K., B. Alloway, P. Almond, D. Barrell, R. Duncan, M. McSaveney, S. Read, and P. Tonkin (2001). Alpine fault rupture and landscape evolution in Westland, New Zealand, Trans. Jap. Geomorph. U. 22, no. 4, C-22.

Bronk-Ramsey, C. (2010). OxCal Program v4 1.7. Radiocarbon Calibration Software, Research Lab for Archaeology, Oxford, United Kingdom.

Cooper, A. F., and D. G. Bishop (1979). Uplift rates and high level marine platforms associated with the Alpine fault at Okuru River, South Westland, J. Roy. Soc. New Zeal. 18, 35-43.

Cooper, A. F., and R. J Norris (1990). Estimates for the timing of the last coseismic displacement on the Alpine fault, northern Fiordland, New Zealand, New Zeal. J. Geol. Geophys. 40, 303-307.

Cooper, A. F., and R. J. Norris (1995). Displacement on the Alpine fault at Haast River, South Westland, New Zealand, New Zeal. J. Geol. Geophys. 38, 509-514.

Cullen, L. E., R. P. Duncan, A. Wells, and G. H. Stewart (2003). Floodplain and regional scale variation in earthquake effects on forests, Westland, New Zealand, J. Roy. Soc. New Zeal. 33, no. 4, 693-701.

DeMets, C., R. G. Gordon, D. F. Argus, and S. Stein (1994). Effect of recent revisions to the geomagnetic time scale on estimates of current plate motions, Geophys. Res. Lett. 21, 2191-2194.

Downes, G., U. Cochran, L. Wallace, M. Reyners, K. Berryman, R. Walters, F. Callaghan, P. Barnes, and R. Bell (2005). Understanding local source tsunami: 1820s Southland tsunami, Earthquake Commission of NZ Res. Rep. 03/490, 92 pp.
Hull, A. G., and K. R. Berryman (1986). Holocene tectonism in the region of the Alpine fault at Lake McKerrow, Fiordland, New Zealand, J. Roy. Soc. New Zeal. 24, 317-331.

Langridge, R. M., P. Villamor, R. Basili, P. Almond, J. J. Martinez-Diaz, and C. Canora (2010). Revised slip rates for the Alpine fault at Inchbonnie: Implications for plate boundary kinematics of South Island, New Zealand, Lithosphere 2, 139-152. doi 10.1130/L88.1.

McCormac, F. G., P. J. Reimer, A. G. Hogg, T. F. G. Higham, M. G. L. Baillie, J. Palmer, and M. Stuiver (2002). The calibration of the radiocarbon time scale for the Southern Hemisphere: A.D. 1850-950, Radiocarbon 44, 641-651.

McCalpin, J. P. (Ed) (1996). Introduction to Paleoseismology, International Geophysics Series 62, Academic Press, San Diego, California, $588 \mathrm{pp}$.

Norris, R. J., and A. F. Cooper (1997). Erosional control on the structural evolution of a transpressional thrust complex on the Alpine Fault, New Zealand, J. Struct. Geol. 19, 1323-1342.

Norris, R. J., and A. F. Cooper (2001). Late Quaternary slip rates and slip partitioning on the Alpine fault, New Zealand, J. Struct. Geol. 23, 507-520.

Norris, R. J., P. O. Koons, and A. F. Cooper (1990). The obliquelyconvergent plate boundary in the South Island of New Zealand: Implications for ancient collision zones, J. Struct. Geol. 12, 715-725.

Norris, R. J., A. F. Cooper, T. Wright, and K. Berryman (2001). Dating of past Alpine fault rupture in South Westland. NZ Earthquake Commission Report 99/341, 134 pp.

Quigley, M., R. Van Dissen, N. Litchfield, P. Villamor, B. Duffy, D. Barrell, K. Furlong, T. Stahl, E. Bilderback, and D. Noble (2012). Surface rupture during the $2010 M_{\mathrm{w}} 7.1$ Darfield (Canterbury) earthquake: Implications for fault rupture dynamics and seismic-hazard analysis, Geology 40 no. 1, 55-58.

Salyards, S. L., K. E. Sieh, and J. L. Kirschvink (1992). Paleomagnetic measurement of nonbrittle coseismic deformation across the San Andreas fault at Pallett Creek, J. Geophys. Res. 97, 12,45712,470 .

Stuiver, M., and P. J. Reimer (1993). Extended ${ }^{14} \mathrm{C}$ database and revised CALIB radiocarbon calibration program, Radiocarbon 35, 215-230.

Sutherland, R. (1994). Displacement since the Pliocene along the southern section of the Alpine fault, New Zealand, Geol. 22, no. 4, $327-330$.

Sutherland, R. (1999). Basement geology and tectonic development of the greater New Zealand region: An interpretation from regional magnetic data, Tectonophysics 308, no. 3, 341-362.

Sutherland, R., and R. J. Norris (1995). Late Quaternary displacement rate, paleoseismicity, and geomorphic evolution of the Alpine fault: Evidence from Hokuri Creek, South Westland, New Zealand, New Zeal. J. Geol. Geophys. 38, no. 4, 419-430.

Sutherland, R., S. Nathan, I. M. Turnbull, and A. G. Beu (1995). PlioceneQuaternary sedimentation and Alpine fault related tectonics in the lower Cascade Valley, South Westland, New Zealand, New Zeal. J. Geol. Geophys. 38, no. 4, 431-450.

Sutherland, R., F. Davey, and J. Beavan (2000). Plate boundary deformation in South Island, New Zealand, is related to inherited lithospheric structure, Earth Plan. Sci. Lett. 177, 141-151.

Sutherland, R., K. R. Berryman, and R. J. Norris (2006). Quaternary slip rate and geomorphology of the Alpine fault: Implications for kinematics and seismic hazard in southwest New Zealand, Geol. Soc. Am. Bull. 118, 464-474.

Sutherland, R., D. Eberhart-Phillips, R. A. Harris, T. A. Stern, R. J. Beavan, S. M. Ellis, S. A. Henrys, S. C. Cox, R. J. Norris, K. R. Berryman, J. Townend, S. C. Bannister, J. Pettinga, B. Leitner, L. M. Wallace, T. A. Little, A. F. Cooper, M. Yetton, and M. W. Stirling (2007). Do great earthquakes occur on the Alpine Fault in central South Island, New Zealand?, pp. 235-251 in D. A. Okaya, T. A. Stern, and F. J. Davey, (Editors), A continental plate boundary: Tectonics at South Island, 
New Zealand. Washington, D.C.: American Geophysical Union. Geophysical monograph 175.

Sylvester, A. G. (1988). Strike-slip faults, Geol. Soc. Am. Bull. 100, 16661703.

Thatcher, W., and M. Lisowski (1987). Long-term seismic potential of the San Andreas fault southeast of San Francisco, California, J. Geophys. Res. 92, 4771-4784.

Wallace, L. M., J. Beavan, R. McCaffrey, K. Berryman, and P. Denys (2007). Balancing the plate motion budget in the South Island, New Zealand using GPS, geological and seismological data, Geophys. J. Intl. 168, 332-352.

Wellman, H. W. (1953). Data for the study of Recent and Late Pleistocene faulting in the South Island, New Zealand, New Zeal. J. Sci. Tech. B Gen. 37, 270-288.

Wellman, H. W (1979). An uplift map for the South Island of New Zealand and a model for uplift of the Southern Alps, J. Roy. Soc. New Zeal. $13-20$.

Wells, A., and J. Goff (2007). Coastal dunes in Westland, New Zealand, provide a record of paleoseismic activity on the Alpine fault, Geol. 35, 731-734.

Wells, A., G. H. Stewart, and R. P. Duncan (1998). Evidence of widespread, synchronous, disturbance-initiated forest establishment in Westland, New Zealand, J. Roy. Soc. New Zeal. 28, 333-345.

Wright, C. A., A. F. Cooper, and R. J. Norris (1997). Paleoseismological potential of the Alpine fault at Waitaha River, Westland, Geol. Soc. NZ, Misc. pub. 95A 171.

Yetton, M. D. (1998). Progress in understanding the paleoseismicity of the central and northern Alpine fault, Westland, New Zealand, New Zeal. J. Geol. Geophys. 41, 475-483.

Yetton, M. D., A. Wells, and N. J. Traylen (1998). The probability and consequences of the next Alpine fault earthquake, Earthquake Commission Contract Report 95/193.
GNS Science

P.O. Box 30368

Lower Hutt, New Zealand

k.berryman@gns.cri.nz

p.villamor@gns.cri.nz

r.sutherland@gns.cri.nz

r.langridge@gns.cri.nz

(K.B., P.V., R.S., R.L.)

Department of Geology

University of Otago

P.O. Box 56

Dunedin, New Zealand

alan.cooper@otago.ac.nz

richard.norris@otago.ac.nz

trevwright@xtra.co.nz

(A.C., R.N., T.W.)

Department of Geology

Western Washington University

Bellingham, Washington

liz.schermer@wwu.edu

(E.S.)

Seismological Laboratory

University of Nevada

Reno, Nevada

glenn@unr.edu

(G.B.)

Manuscript received 19 June 2011 